\title{
"Cemetery=Civilization": Circus Wols, World War II, and the Collapse of Humanism
}

\author{
Iveta Slavkova
}

Department of Art History and Fine Arts, The American University of Paris, 75007 Paris, France; islavkova@aup.edu

Received: 22 April 2020; Accepted: 13 August 2020; Published: 26 August 2020

check for updates

\begin{abstract}
Circus Wols is a multimedia spectacle conceived by Wols during World War II at the Camp des Milles where he was interned between May and October 1940. As a German citizen, the artist was considered an enemy of France and Circus helped him bear the harsh conditions of his imprisonment. Wols envisioned a show of high intellectual and aesthetic value that would employ advanced technology but remain accessible to the masses. As such, it is comparable to a utopian avant-garde total artwork. However, through its assumed incompletion and fragmentation, Circus Wols destabilized the ambitions of the avant-garde and modernism; it even went further, rejecting anthropocentrism. Shortly after his liberation from the camp, Wols began to claim that his art should not be considered a human creation. Prefigured by Circus Wols, the artist's dismissal of European humanism as a valid social and cultural paradigm only grew after the war. His stance is best understood in relation to the contemporaneous notion of "abhumanism", first theorized by playwright Jacques Audiberti, and embraced by Wols's close friend, artist and poet Camille Bryen. The article argues that approaching Wols through the lens of abhumanism highlights the pressing historical concerns of his work, which, associated with post-war Parisian Abstraction, is usually depoliticized.
\end{abstract}

Keywords: Wols; World War II camps; artistic immigration; artist's books; utopia; humanism crisis; posthumanism; abhumanism

\section{Introduction}

Like many other German citizens residing in France, Otto Wolfgang Schulze (1913-1951), known as Wols, was arrested in September 1939 when France declared war on Germany. He was interned in several camps for subjects considered enemies. The Camp des Milles, a former tile factory near Aix-en-Provence, where he arrived in May 1940, was one of them. There, Wols initiated an immersive totalizing utopian project called Circus Wols. Though it remained a work-in-progress, Wols seemed to attach particular importance to the Circus. He mentioned it proudly in his US visa application at the Emergency Rescue Committee directed by Varian Fry in Marseilles (reproduced in Caille and Laffon 2013, p. 103). He continued to focus on it in the form of a book project in the village of Dieulefit where he resided after his liberation. He also mentioned explicitly to collector Pierre Lévy that he dreamt of compiling a book in order not to disperse his documents (Van Damme 1985c, p. 12). ${ }^{1}$

Circus Wols oscillates between dreamy enchantment and anguish reflecting Wols's oscillation between the staggering hope for liberation and the oppressive sensation that there is no escape. On the one hand, it bears similarities to the utopian modernist total artwork: Wols planned it as

1 "Moi je rêve de réaliser un livre et de ne pas disperser avant les documents". The original French texts will be systematically given in footnotes. Unless otherwise stated, all translations of Wols, Audiberti and Bryen are mine. Some of Wols's aphorisms can be found in English in scattered publications but there is no reference edition. 
an all-encompassing educative democratic spectacle, based on popular and erudite culture, using advanced technology in the service of the visual arts, cinema, music, and theater made accessible to everyone. On the other hand, its purposefully fragmented structure and the artist's unwillingness to advance any singular meaning or grand discourse turns Circus Wols into a dystopian project that prefigures post-modernism.

I will argue that the project is founded upon an interrogation of the humanist paradigm that had dominated European culture for centuries. Not only does it instill doubt in anthropocentrism, but it demonstrates resilience in the face of the inherent violence of human nature, as revealed by the two global conflicts-World War I and World War II-occurring in rapid succession in the very heart of the European continent that perceived itself to be the summit of human civilization. As we are going to see, Wols's skepticism about humanism is continuously reiterated in his writings and artworks after his liberation from the Camp des Milles in October 1940. More and more often, he referred to humans simply as "bipeds", which expresses a refusal to believe in humanity's capacity to construct a better future fueled by the grandeur of humanism. Yet, his continued artistic practice expresses a paradoxical confidence in the act of creation.

A year after Wols's death in 1951, his friend, the artist and poet Camille Bryen (1907-1977), emphasized this anti-humanist aspect of his work and called him the being "the least recessed in the species" (Audiberti and Bryen 1952, p. 119). ${ }^{2}$ The citation comes from L'Ouvre Boite. Colloque abhumaniste (The Can-Opener. An Abhumanist Colloquium) which was co-written by Bryen and the playwright Jacques Audiberti, two historically underestimated intellectual figures of the post-war Saint-Germain-des-Prés community. Audiberti coined the term "abhumanism" in 1946 (Audiberti 1946) and intended to question humanism as a valid paradigm after the catastrophic world wars. Abhumanism took its cues from Dadaism and Surrealism-Audiberti had many contacts with the latter, Bryen with both, and Wols revolved around surrealist dissidents, some of them former Parisian Dadaists-and responded critically to the claims of Jean-Paul Sartre, the most notorious of Wols's champions, for a renewed humanism.

This article will first describe Circus Wols based on available archives (Section 2.1) and drawings (Section 2.2). The subsequent discussion will focus on its oscillation between joyful fantasy and gruesome war experience (Section 3.1) as well as its paradoxical combination of humanist utopianism and rejection of the humanist paradigm. It will then critically analyze the criteria and methodologies according to which Wols has been considered in art history (Section 4.1), exposing the relevance of abhumanism to Wols's oeuvre (Section 4.2). It is my contention that considering Wols's project as an abhumanist response to World War II underscores the historical importance of both Circus Wols and abhumanism, suggesting a reconsideration of post-World-War-II cultural history as well as a historical precedent for such contemporary notions as posthumanism (Section 5).

\section{The Circus Wols Project}

\subsection{Written Sources}

In 1932, at the age of 19, Otto Wolfgang Schulze settled in Paris, and adopted the artistic pseudonym of Wols five years later (Rathke 2013, p. 44). The reasons for his move are not clear; pushed by a conflictual relationship with his family, the young man was very probably attracted by the artistic effervescence of the French capital. To date, there is no sufficient evidence that his motivation was political and that he fled Nazism. Though, in 1933, Wols expressed in an aphorism his discontent with the growing influence of National Socialism in Germany-"A syphilitic population is cleaner than a gestapolized population" (Van Damme 1985a, p. 219) — - there is no record of him being politically

2 "l'être le moins enfoncé dans l'espèce".

3 "Une population syphilitique est plus propre qu'une population gestapolisée". 
active in Paris. Unlike other German artist-immigrants, he was not a member of the "Union des artistes libres", the political union of German artists in France (Foster-Matalon 1991). His arrest in 1935 by the Spanish government on suspicion of being a German spy (Rathke 2013, p. 41) does not seem to have sharpened his political awareness. As his correspondence shows, Wols struggled to secure legal documents to stay in France and had the support of the Parisian artistic milieu. Florent Fels, the director of the influential magazine $V u$, the fashion designer Jeanne Bucher, and the painter Fernand Léger all wrote letters of recommendation that praised his artistic skills (Van Damme 1985b, pp. 11-14). Wols eventually was appointed official photographer of the "Pavillon de l'Élégance" at the International Exposition of 1937, which gained him a certain notoriety and a number of commissions (Van Damme 1985c, pp. 67-81).

Despite his growing success, Wols's situation drastically changed in September 1939 due to the declaration of war between France and Germany. Considered an enemy because he was a citizen of the Reich, Wols was interned in a succession of camps for undesirable foreigners. In May 1940, he entered the Camp des Milles near Aix-en-Provence (Rathke 2013, pp. 46-47). Though it later became notorious as an antechamber to Auschwitz, in the spring of 1940, it functioned as a transit camp where numerous foreign artists and writers were held prisoner (Caille and Laffon 2013, pp. 21-24). Stripped of his camera and dreaming of escape, Wols started a project encompassing all the fields of human thought and creativity, a kind of total work of art, which he entitled Circus Wols. Evidence of the project is found in Wols's archives during and just after his imprisonment at Milles. A few drawings illustrate the scenography and the facilities intended by the artist.

The archival documents for Circus Wols are fragmented and hard to decipher, as is common for Wols. Belgian scholar Claire Van Damme, has transcribed, classified, and dated them in her edition of the artist's writings (Van Damme 1985a, pp. 21-58). Her pioneering work enabled me to suggest a synthesis and global interpretation of the project in 2004 (Slavkova 2004) which were further developed in 2018 (Slavkova 2018). In both, I argued that despite the chaotic order in which these documents have come down to us, Circus Wols is a particularly coherent project (Slavkova 2004, pp. 154-56). While it is true that poems, aphorisms, diagrams, technical annotations, and interjections referring to philosophy and literature seem to be juxtaposed without hierarchy, careful scrutiny reveals that the artist's thought and process did not lack structure.

The sheet entitled Rumba I offers proof of the organized nature of the project and its archive (Figure 1). Rumba I is a detailed description of a multimedia dance show that was part of Circus Wols (Van Damme 1985a, pp. 50-55; Slavkova 2018, pp. 332-34). The artist annotated different portions of the text within a careful system of notation, with sections of the body text associated with a "dossier III" (folder III), as the mark in the left top corner indicates, and a tightly written commentary at the bottom of the page dispatched to a "dossier II" (folder II). In the global organization of Circus Wols, the folder III encompasses notes on the material and the props (original title "Matériel"); folder II is entitled "Thoughts" ("Pensées") and involves more subjective comments (Van Damme 1985a, p. 45). This separation makes perfect sense in Rumba I: the body text establishes concrete guidelines for the material organization as it highlights the number of participants, necessary technical tools, choreography, scenography, music, etc. The note at the bottom is of a different nature. Providing an anthropological analysis of the rumba as a dance, Wols also critiques its appropriation by Europeans. More generally, in Rumba I Wols employs the same abbreviations that appear elsewhere in the project (archives and drawings). For example, he alludes to tools mentioned throughout Circus Wols: the "polyscope" for example, a kind of a camera capable of projecting enlarged holograms on stage, and of which we'll speak later. 


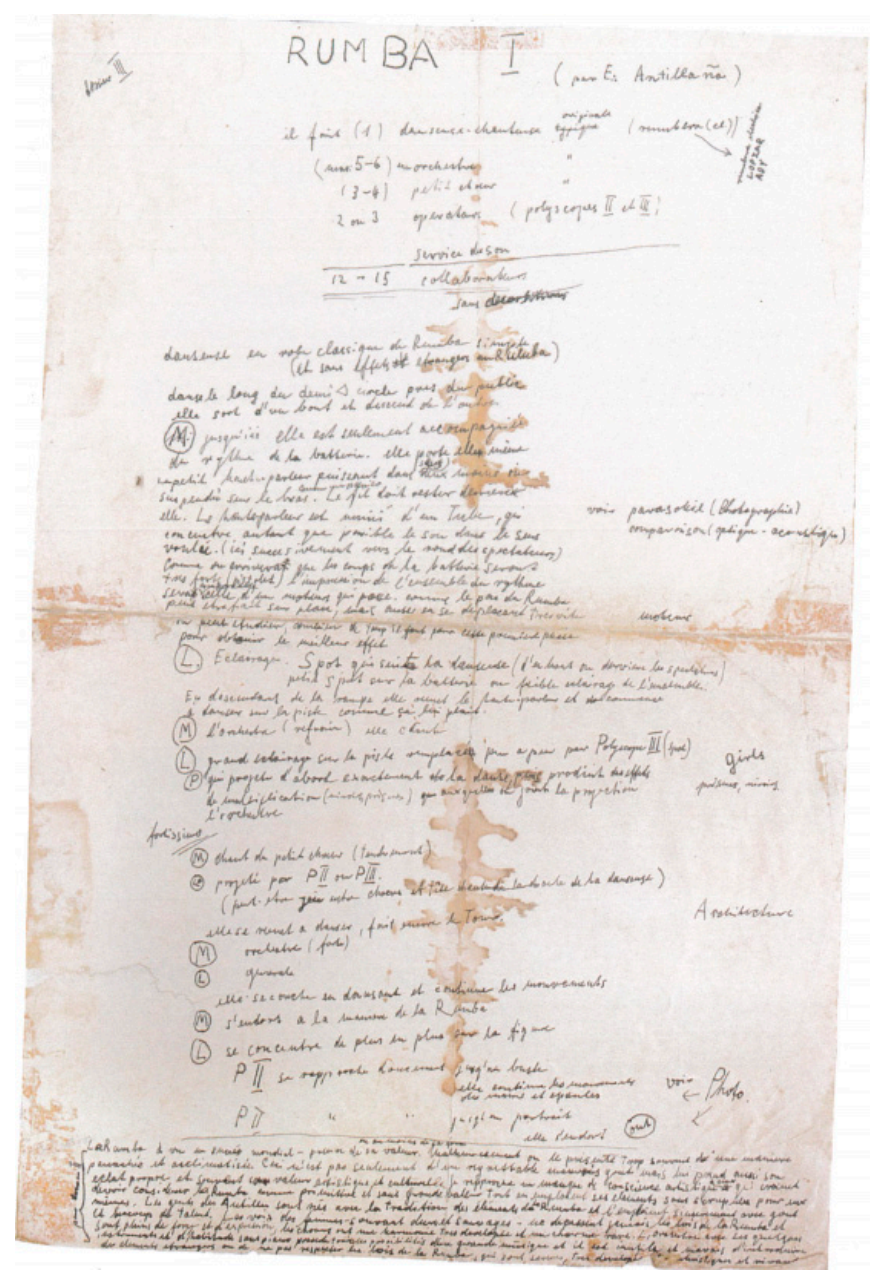

Figure 1. Wols, Circus Wols: Rumba I. Music show conceived at the Camp des Milles, 1940. Private collection. (C) Adagp, Paris, 2020.

While there is both a conceptual and organizational structure to the Circus Wols, its apparent disorder may be at least partly intentional. The artist intended the project as a totalization and democratization of the best of human thought-including the humanities, arts, and science-under the form of a popular spectacle. At the same time, he wished to leave space for the public to adjust and interact freely. He explained that the above-mentioned annotations should enable the public to "travel" from one folder or topic to another (Van Damme 1985a, p. 46). Thus, the arrows, present in the manuscript and drawings, embody his will to "leave the folders, the phenomena, the subjects, etc. continuously in relation between them in all directions" (p. 46). He also refused the hierarchal subsumption of the detail under the whole by designing interactive and open-ended folders in order to "obtain a result either for the ensemble or for the detail" (p. 46). ${ }^{4}$

Other written sources show how important Circus Wols was for the artist. In his application for a US visa at Varian Fry's Emergency Rescue Committee in Marseilles, Wols dedicated an entire paragraph to the project in his "Biographical sketch" or CV (Van Damme 1985a, pp. 64-66). The document was prepared while he was staying in the town of Cassis, near Marseilles, after his liberation from Milles in October 1940. Claire Van Damme and Hans-Joachim Petersen (Petersen 2010, pp. 138-39) date it from

4 “avec les flèches je veux montrer que je laisse les dossiers tous les phénomènes sujets etc. continuellement en relations (sic) entre eux dans toutes les directions. Quand j'aperçois un problème un sujet etc ... je vais le mener par tous les dossiers pour obtenir un resultat (sic) soit pour l'ensemble soit comme détail, soit pratique soit [unreadable]". 
1940-1942 (Wols left Cassis for Dieulefit in November 1942), whereas the recent exhibition on interned artists at the Site-mémorial du Camp des Milles restricted the dating to 1940 (Caille and Laffon 2013, p. 103). In all cases, the document predates the summer of 1941. Fry was forced to return to the United States in August 1941, and it is certain that he was acquainted with Wols's case because he bought and took with him two of the artist's drawings (reproduced in Wols 1989, p. 111). Here is the paragraph in English describing Circus Wols in the CV:

[ ... ] My chief manuscript on which I worked since (sic) two years is intitled (sic): "Circus Wols" [.] This work is a manuel (sic) not only conceiving a new kind of employing technic (sic) but also meaning to establish a relationship of art in general, science, philosophy and human life. This "Circus Wols" is a suggestion to create in a democratic manner the education of taste and public opinion, popularising spheres that up to now were reserved to certain classes only.

Here I miss the possibility of collaboration and research as well as the moral and artistic spons[ors]hip (sic). I hope to interest rapidly minds and institutions in U.S.A (sic) for my work or part of my work [ ... ]

There would be possibility for "Circus Wols" by the relations of Dr. Wilezinsky to Mr W. Zilzer 8301 Kirkwood Drew Hollywood. Cal. and to Dr. Paul Wohl 547 5th av. N. Y [ ... ]." (Van Damme 1985a, p. 66)

Wols's attempted formality and intellectual rigor are thwarted by the vagueness of his statements. The advancement and the content of the project are not clearly specified, and neither is the nature of the support he hoped to receive in the US. His goals and motivation-democratization; general education of taste; connecting all the arts, science, and technical progress-would appear grandiloquent if the style were not so awkward and the hesitations so apparent. For instance, Wols stated that he hoped the Americans would be interested in the project, but added hesitantly "or a part of my work". His uncertainty echoes the above-mentioned oscillation between an impulse towards totalization, inspired by avant-garde utopias, and the desire to escape all fixity. Additionally, Wols's CV failed to grasp the nature of the visa program. Varian Fry had been mandated to issue emergency visas for intellectuals and artists in danger of death and persecution under fascism. Although he broadened the program's initial focus on celebrities to incorporate less known artists, he was obliged to assess applicants according to the gravity of their plight (Kessin Birman 1997, pp. 102-4). Wols's naïve remark concerning the lack of support for his Circus in France could hardly prioritize him for immigration. In addition, the marriage with his girlfriend Gréty Dabija provided him with French citizenship and stabilized his situation.

Wols's doubts are reiterated in yet another document entitled "Préface", in French, written in capital letters like the CV (reproduced in Caille and Laffon 2013, p. 104). According to Peterson, this document was a complement to the biographical sketch and was written during his imprisonment at Milles (Petersen 2010, p. 134). However, one could also consider it a projected preface, summarizing his motivations, for the book Wols hoped to produce. References to such a book are found in the Wols material contained in the Iliazd fund at the Centre Pompidou (Wols, fund Iliazd 1940-1944, 3871) as well as in his contemporaneous correspondence (Van Damme 1985c, p. 12). "Preface" focuses on the circumstances in which Circus Wols was conceived. It is less formal and more intimate than the CV. The narrative opens with a statement of Wols's difficult and uneven youth, and presents Circus Wols as a solution to the uncertainties of his life:

[... ] During one year of concentration [or in concentration camps? ${ }^{5}$ ] the necessity dawned on me to generalize all my problems towards the unknown goal of my life; I therefore created a

5 I have translated the document and have not used the English version proposed by Peter Inch in 1978 (Inch 1978 , n.p.). Too fluent, the latter overlooks the ambiguities and awkwardness of Wols's original text. For instance, "Pendant un an de 
hypothesis I call "Circus Wols". I believe this name is logical because the circus contains all the possibilities, be a central of all my occupations (sic), even if it will never be realized [ .. ] ${ }^{6}$ (Petersen 2010, p. 135)

Wols calls Circus Wols a "hypothesis" contradicting his own definition that it is the solution to his problems. Again, the ambition to encompass all possibilities is thwarted by the doubt that such a project could ever be realized.

\subsection{Drawings}

Three ink and watercolor drawings explicitly related to the project complete the portfolio Circus Wols. The factual information concerning them (title, provenance, exhibits, etc.) is based on the most recent Bremen/Houston catalog (Wols 2013, pp. 252-53).

Circus Wols, dated from 1940, is signed and the initials CW (for Circus Wols) are present at the top, in a small square (Figure 2). The watercolor offers an idea of the general atmosphere of the project and the kind of performances Wols projected. The show takes place in an arena encircled by red bricks, reminiscent of the brick chimney in the camp, still intact today (Mémoire du camp des Milles 2013, pp. 80-83). The brick wall and the brick tower are recurring motifs in the works of the majority of the artists who spent some time in the ancient tile factory and Wols was no exception (Caille and Laffon 2013, pp. 32, 35, 36, 39, 40, 45, 51, and 62).

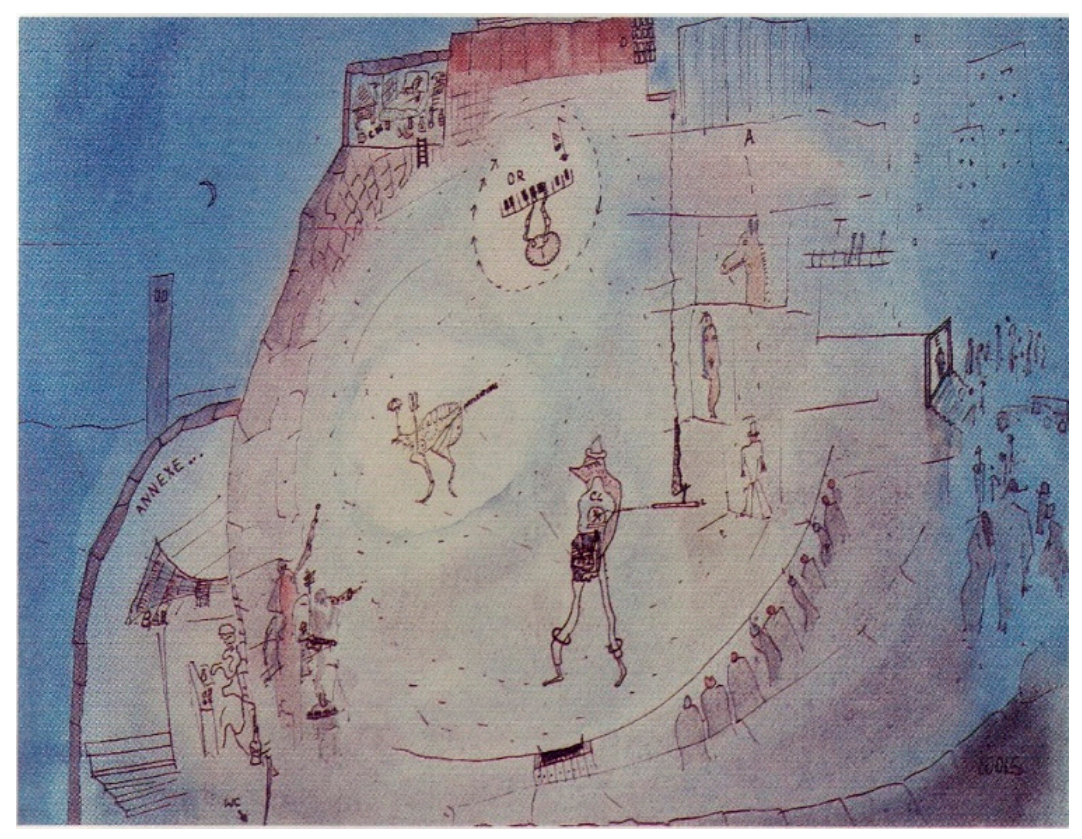

Figure 2. Wols, Circus Wols, c. 1940. Ink and watercolor on paper, $24 \mathrm{~cm} \times 31.5 \mathrm{~cm}$. Private collection.

(C) Adagp, Paris, 2020/Courtesy Karin und Uwe Hollweg Sammlung.

In Circus Wols, the tower is seen obliquely, sectioned so that the spectator is peeping into it from above. There is an entrance to the right (marked by the letter " $E$ ") around which a loose crowd is converging. There is a bar to the left, situated in a room marked "ANNEXE", with a restroom ("WC")

concentration" is unambiguously translated into "I have been interned for a year now". The document does not mention any concrete events and insists rather on the intellectual genesis of Circus Wols, so "concentration" might just refer to a period of intense intellectual work. Wols often makes puns in French so the ambiguity might have been intentional.

6 "Pendant un an de concentration la nécessité m'est advenue de généraliser tous mes problèmes pour le but inconnu de ma vie; j'ai donc créé une hypothèse que j'appelle: Circus Wols. Je crois ce nom logique parce que le cirque contient toutes les possibilités, d'être une centrale de mes occupations (sic), même s'il en sera jamais réalisé". 
downstairs, typical of Parisian cafés. There is a small room on top, adjacent to the red roof, when one can see a figure lying on a bed with a bottle by his side, probably the artist himself as the impresario of Circus Wols (Wols suffered from alcoholism aggravated by his multiple camp internments) (Slavkova 2011, p. 94). To the roof's right, there are a number of large screens with simultaneous projections of animals and a naked woman. In the middle of the arena, a sort of giant flea is performing under the spotlights. It is holding an umbrella and a fan, two objects characteristic of circus tightrope walkers. An inscription defines it as belonging to the family of arthropods ("ARTHROPODES"). The giant arthropod forms the top of a triangle whose two other corners are a mechanical piano, designated by "OR" (orchestra?), and a fantastical, zoo-anthropomorphic figure with rings on the ankles, designated by "CL" (clown?). Wols has explicitly connected this creature to the insect through another dotted-line triangle. If we scrutinize the clown's torso, we see a tiny insect, either strongly illuminated or held under a glass cup (or both?), whose silhouette is very similar to the tightrope arthropod.

Wols has connected the tiny insect to a rod perpendicular to the torso, marked by the inscription "L" (like light or "lumière" in French; the letter "L" also stand for light in the manuscript Rumba I). In the lap of the zoo-anthropomorphic clown, under the insect, there is a loosely sketched mechanical device from which two dotted lines emerge and progressively diverge to enclose the giant arthropod on the stage. The configuration of the stage, screens, light-source, and mechanical device recalls Wols's diagram of a "polyscope" also found in the archives (Figure 3; Van Damme 1985a, p. 58). The polyscope consists of a recording lens and a projection lens, associated with movable mirrors and intermediary screens. As it is illustrated in the watercolor, a source of light is necessary for its functioning, as well as a stage and a screen. In another sheet, Wols explains that his invention allows for optical trickery, namely multiplications and amplifications (Van Damme 1985a, p. 57).

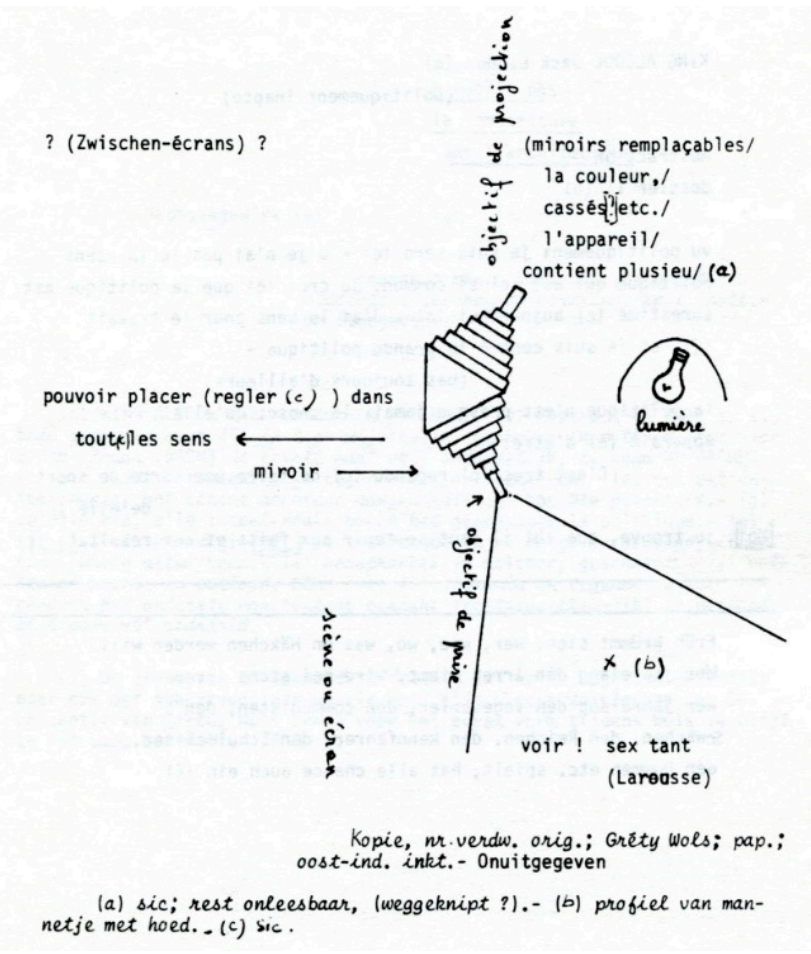

Figure 3. Wols, The Polyscope, archives Wols, folder Circus Wols. Transcription Claire van Damme, 1985. Used with permission/Courtesy Claire Van Damme.

According to the artist's concept, projections would be emitted in all directions and a third lens could be used to deform and further multiply the viewpoints. The Wols expert Ewald Rathke sees the polyscope as a camera capable of enlarging elements and projecting them on a screen (Rathke 2013, p. 47). In her insightful study of Wols's photography, art historian Christine Mehring relates 
the polyscope to Wols's photographic work where close-ups and magnification serve to dissolve the real (Mehring 1999, p. 19). She notes that "a sense of unreality is also created as motifs are seemingly projected into the air —as if dematerialized - rather than onto a screen" (p. 19). Indeed, the arthropod in Wols's drawing does not seem to be a 2D projection but an enlarged "digital" double that may be immaterial but whose presence on the stage is very real. I agree with Mehring that the polyscope is the artist's imagination of a futuristic device, a sort of 3D video-projector producing hologram-like "simulacra" on stage.

The second drawing of the Circus Wols portfolio was named The Circus I Adore, after the inscription on the back of an old mounting by an unidentified hand: "Wols ... the circus I adore ... 1940 Camp des Milles, near Aix-en-Provence" (Figure 4; Wols 2013, p. 235). The general disposition of the previous drawing is globally respected: an arena under spotlights in which a zoo-anthropomorphic creature is running, a bar to the left designated by the alcoholic drink "PORTO" with silhouettes drinking at a counter. The audience tends to meld with the brick walls, a process suggested in the previous drawing through the rectangular brick-like bodies, but rendered more explicit here.

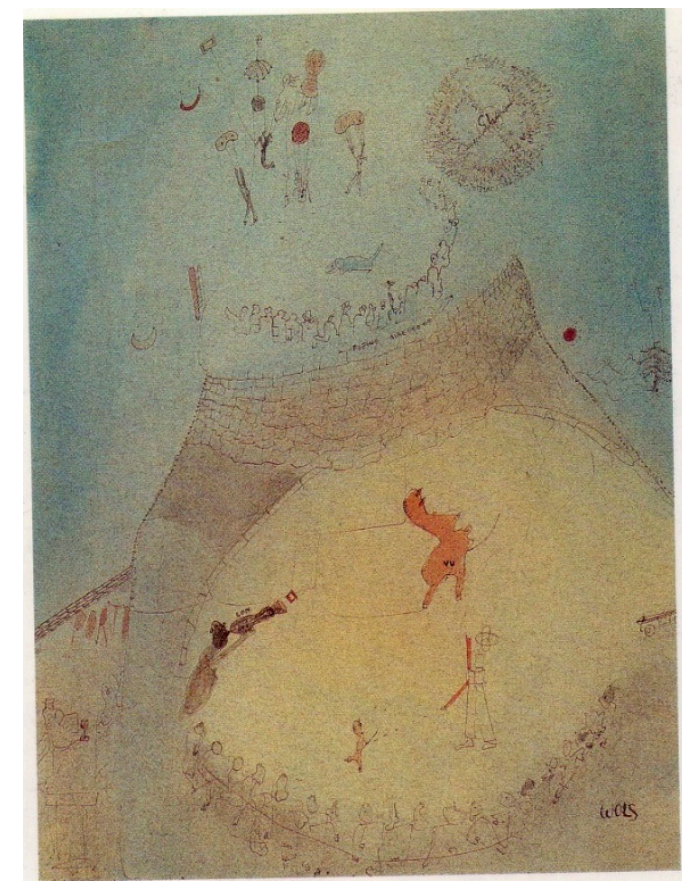

Figure 4. Wols, The Circus I Adore, c. 1940. Ink and watercolor on paper, $31.5 \mathrm{~cm} \times 23.5 \mathrm{~cm}$. Private collection. (C) Adagp, Paris, 2020.

The central creature here is of a vivid orange, contrasting starkly with the black and white flea of Circus Wols. Compared to the previous arthropod, this one is gendered, with clearly defined breasts and large buttocks. Just below her, a roughly sketched disincarnated figure with a top hat seems to juggle with two orange rods, maybe a polyscope, in front of a smaller, orange, but less bright creature. While not perfectly identical, the two orange silhouettes are very similar, as if they were captured performing slightly different movements at two different times. Here too, dotted lines connect the polyscope rods to both creatures, suggesting that the bigger one is a projection of the smaller.

A second arena in the background of The Circus I Adore marks a notable difference with Circus Wols. It is situated on an elevated terrace designated by the inscription "PLEINE AIREEEEEE", a pun with the French expression "plein air" which means outside. The inscription is "transpierced" by an arrow which, according to the instructions given by Wols in the archives, means movement and free circulation in all directions. In the context of Wols's imprisonment, these elements must have referred to his desire to leave the camp and circulate freely. This idea is confirmed by the presence of 
parachutists, floating above the brick tower as if it is not an obstacle for them. The parachutes have fantastical forms: some are anthropomorphic, others zoomorphic; some recall objects, for instance, a painter's palette or a picture frame.

The circle made of whirling overlapping words to the upper right is also a new motif. Close attention and a magnifying glass are needed to decipher the inscriptions. One can read "Art", "Surréalisme", "Sciences", "Conscience", "Cercle vicieux" (vicious circle), "Einstein", "Polyscope", "Ruisseau" (creek), "Filou" (trickster), "Rognon" (kidney), "Puce" (flea), etc. (Wols 1989, p. 118). The mundane is mingled with philosophy, art, and science. There is one circle in the Circus Wols archives which particularly resembles this one (Figure 5; Van Damme 1985a, p. 29). As in the previous watercolor, Wols has abbreviated "Circus Wols" to CW in the middle. Two diagonals separate the circus in four parts, corresponding to the four main folders ("Ideas", "Art", "Thoughts", "Material"). The inscriptions here have a more practical connotation: "education", "meeting room", "drawings", "utopias", etc. Though seen only in this drawing, the circle appears regularly in the archives, under different forms (Van Damme 1985a, pp. 24, 28, 29, 32). In Latin, "circus" means also circle, a symbolic geometrical form suggesting the infinity of the universe.

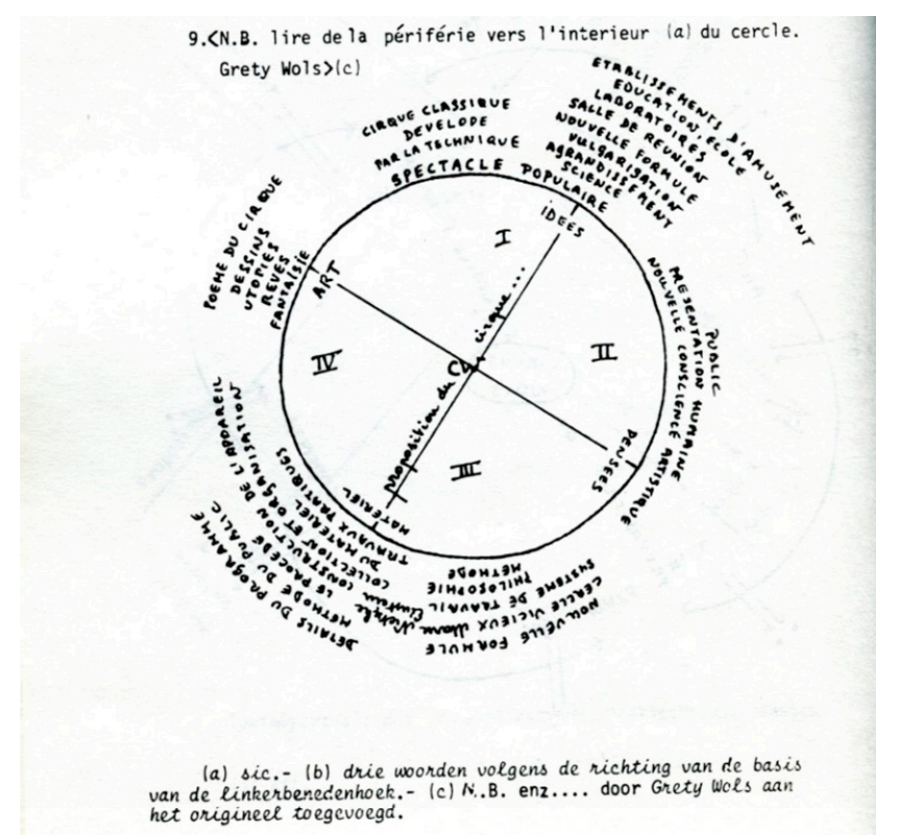

Figure 5. Wols, Circus Wols circle, September 1940. Archives Wols, portfolio Circus Wols. Transcription Claire Van Damme, 1985. Used with permission/Courtesy Claire Van Damme.

The composition of the third drawing, The Circus; Simultaneous View and Projection, is once more centered on an illuminated arena encircled by a brick wall (Figure 6). The configuration is slightly different with certain elements of the two previous works repeated: the public fusing with the brick wall, the screen, the arena, the red brick tower, the fantastical zoo-anthropomorphic figures. Two monstrous silhouettes, who seem on the verge of liquefying, are embracing each other to the left under a big spotlight. The taller one, whose single eye is wide open, penetrates the other, who is sleeping, with his/her barb-like tongue. A camera with a polyscope is set in the center of the arena below them, and their enlarged effigies are projected on a large oval screen. To the right is placed a second fanciful couple. A giraffe, whose visible cellular structure recalls a course of bricks, is grazing on the long black hair of the woman with whom it is paired. An unidentified biomorphic motif-a phallic medusa or fish-is superposed on them. There is a small, roughly sketched orchestra playing music behind the screen. 


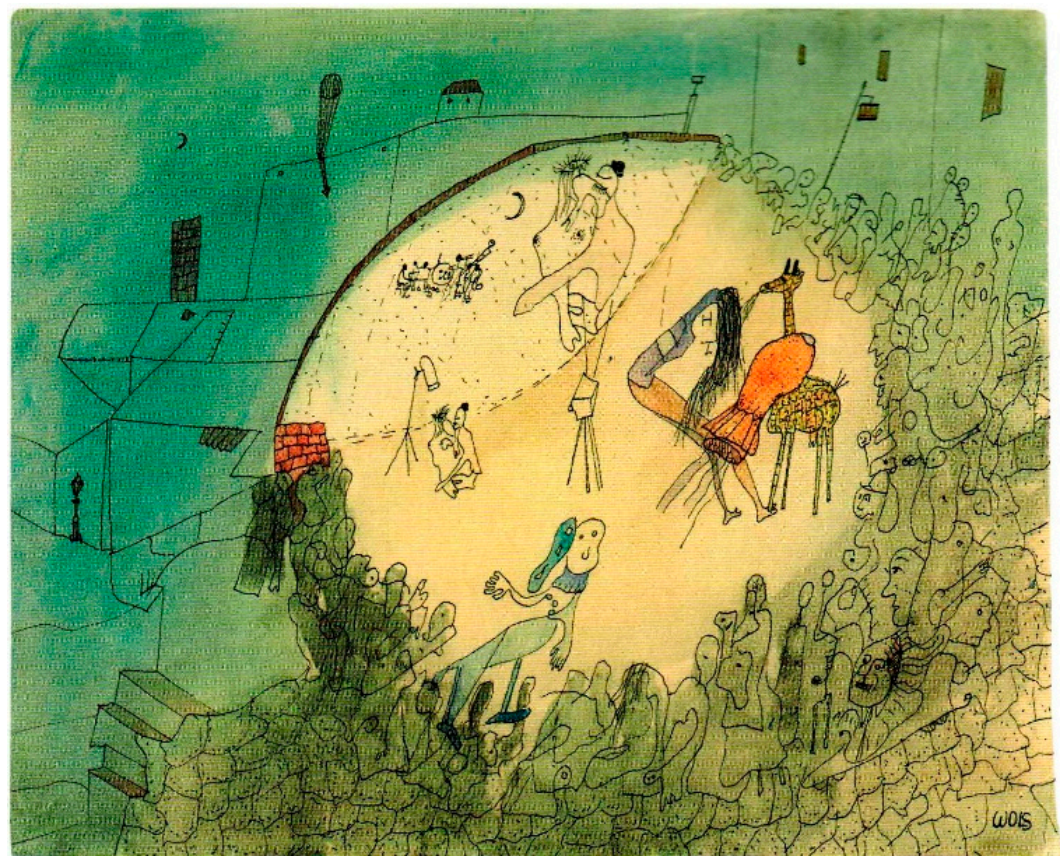

Figure 6. Wols, The Circus; Simultaneous View and Projection, c. 1940. Ink and watercolor on paper, $23 \mathrm{~cm} \times 29 \mathrm{~cm}$. Bremen, Karin und Uwe Hollweg Sammlung. (C) Adagp, Paris, 2020/Courtesy Karin und Uwe Hollweg Sammlung.

In both Circus Wols and The Circus I Adore, there is a small car, cropped by the frame in the right lower part. Like the parachutes, these engines probably allude to the desire to circulate free. Behind the oval screen in the Circus, we also see a ghostly, ship-like structure. Ships figure frequently in Wols's drawings of the period (Wols 1989, pp. 109, 110, 111, 114, 116). They are often shipwrecked, stuck on a hill, or falling into pieces. Like the transparent liner-phantom in The Circus; they allude to Wols's fragile hopes for departure and new life. The artists who were granted visas through Varian Fry's committee departed by ship from Marseilles, Spain, or Portugal. Moreover, rumors circulated among the visa applicants at the Emergency Rescue Committee about mysterious phantom ships, sunk without a trace, reflecting the anxious uncertainty in which these people were stuck (Grandjonc 1999, pp. 51-52).

\section{Circus Wols: A Slippery Fairyland for the Humanist Utopia}

\subsection{Gruesome/Delightful Entertainment}

While conceiving Circus Wols, the artist was aware that his life was in danger and that his fate depended upon the uncertain success of an unpredictable sequence of procedures. Varian Fry explained in Surrender on Demand that a mix of rational planning and chance decided the fate of the refugees: an unexpected detail could compromise a carefully prepared departure (Fry 1945, pp. 52-55, 122-29). Recourse to imaginary worlds, inspired by fairy tales, cinema, and the circus, was a means to escape this stifling uncertainty, to project oneself into a more joyful atmosphere. Such subjects were frequently treated in detention camps and according to historian Peter Kuon, they helped the prisoners endure the gravity of the situation and preserve their humanity (Kuon 2008, p. 178).

For Wols, dreamlike atmospheres were certainly a means of managing his anguish, but the nightmarish, liquefying, dancing, and embracing hybrids also suggest the frequent, if not permanent, state of alcoholism. A bar is represented regularly in the Circus Wols watercolors as well as in other works from the camp. There is sometimes a counter, more often just bottles and glasses scattered across the composition (Slavkova 2011, pp. 89-95). This motif was very probably inspired by Die Katakomben, the improvised bar that actually existed at the Camp des Milles (Bertrand-Dorléac 1997, 
p. 25). The name referred to an expressionist cabaret in Berlin closed by the Nazis, and the "venue" was situated under the dark vaulted corridor on the ground floor of the main building (Paire 2013, p. 65). There, prisoners could purchase opium and alcohol, and stage provocative performances dressed as transvestites, often in a state of drunkenness (p. 65).

These shows, which may have inspired Circus Wols, abated the monotony of detention and sense of imminent danger, and allowed artist-prisoners to continue creating. As a transit camp for undesirable foreigners, Milles also housed Max Ernst, Hans Bellmer, Ferdinand Springer, Karl Bodek, and Leo Marschutz (Caille and Laffon 2013, p. 22). Graffiti are still visible on the walls today, a reminder of an effervescent creativity that led to the realization of more than 400 works by prisoners (Mémoire du camp des Milles 2013, pp. 204-7). In 1939-early 1940, creation was sporadic and disorganized, dominated by the avant-garde artists Ernst, Bellmer, or Springer (Gausmann 2013, pp. 46-49). After 1940, however, the creative potential of the camp was oriented towards commissioned works, such as the murals of the staff refectory executed by Franz Meyer, Max Lingner, and Karl Bodek (pp. 46-47).

In addition to personal anguish and alcoholism, the morbid erotic fantasies in the Circus Wols drawings - the stinger/tongue penetration and severed flying phallus, the monstrous female nudes and feminization of insects, the fusion of deformed bodies-speak to the artist's affective isolation. Another German-born artist, Hans Bellmer (1902-1975), who was part of the surrealist circles, also produced drawings of morbid sexual fantasies at the Camp des Milles, where he was among the first prisoners in September 1939 (Caille and Laffon 2013, pp. 24, 39, 51,62). In the work of Wols and Bellmer, the suicidal embrace of Eros and Thanatos did not originate with their stay at Milles. The motif of the eroticized brick wall (so typical of artworks created at the camp), both inhibiting and protective, was not new for Bellmer (Taylor 2000, pp. 46-52). Similarly, Wols's early drawings already displayed liquefying bodies and monstrous couples (Wols 1989, pp. 30-31). However, it is safe to assume that the artists' erotic anxiety was amplified by the existential plight in which they found themselves during the Second World War. In the case of Wols, morbid erotic motifs were multiplied at Milles.

So the themes developed in Wols's drawing from the Camp des Milles, where the artist spent six months, drew on the immediate environment. In addition to the allusion to the bar Die Katakomben and its nightmarish erotic performances, the most obvious reference to the camp is the red windowless brick tower based on the chimney of the tile factory, which appears in the drawings as a keep, a metaphor for non-escape. In one untitled drawing from the camp, which does not belong to the Circus Wols portfolio, the brick tower is represented as an impenetrable fortress (ink and watercolor, private collection; reproduced in Wols 1989, p. 111). Three filiform ladders are hoisted from the inside like sticks suggesting the presence of invisible long-forgotten prisoners. On one of them is thrust a top hat resembling the one worn by the wire-like disembodied figure in The Circus I Adore. This drawing belonged to Varian Fry, who brought it to New York and whom Wols knew personally, as his photographs of the Emergency Rescue Committee office in Marseilles attest (Glozer 1980, pp. 106-8). Considering the circumstances, the motif of the imprisoned circus could be interpreted as a plea, or sort of SOS to save Wols's artistic universe, and more largely free art and thought.

As we already mentioned, another motif related to the camp is the overwhelming presence of bricks which often blend with the figures. The bricks haunted many of the artists interned at Milles, and red bricks litter the site even today (Mémoire du camp des Milles 2013, pp. 73-191). We also find the fusion of flesh and brick in the work of Ferdinand Springer (1907-1998), who was interned between November 1939 and May 1940 (Caille and Laffon 2013, p. 23). In Dream, for instance (1940, pencil, ink on paper, 1940, private collection; reproduced in Caille and Laffon 2013, p. 32), the classical male nude becomes transparent and his skin blends with the bricks of the tower-like structure behind him. Similarly, Bellmer's drawings often refer to the "brick-becoming" as seen in his Sketch for a Portrait of Max Ernst (1939, graphite and opaque watercolor on paper, New York, Brooklyn Museum of Art: https://wwww.brooklynmuseum.org/opencollection/objects/115040). The surrealist artist Max Ernst (1891-1976), incarcerated at Milles at the same time as Bellmer, is represented as a brick construction 
in the early stages of collapse. The face appears emaciated and the eyes are surrounded by shadow, suggesting insomnia and exhaustion.

Insects are another of the recurring motifs in Wols's drawings that reflect the sanitary conditions in the camp. Milles was an unhealthy and promiscuous place, rife with bacterial infections and parasites (Paire 2013, p. 65). The prisoners slept in flea-infested straw on the floor of a common dormitory, and their daily environment was filled with flies, mosquitoes, and lice. It comes as no surprise that Wols represented insects, and often in the midst of nightmarish desert landscapes.

It is, however, interesting that Wols's drawings often show the insects as performing artists rejoicing in the spotlight. A tightrope-walking flea was among the stars of his circus, prominently occupying the center of Circus Wols watercolors. A drawing that belonged to Varian Fry features a flea acrobat walking on stilts (1940, ink and watercolor, private collection; reproduced in Wols 1989, p. 111). In both cases, the insect is drawn precisely, based on close observation of its physiology. In Circus Wols, the artist has faithfully reproduced the contrast between the insect's large body and small head, emphasized the multiple tentacles around the mouth, and underscored the strength of the posterior legs which enable the flea to be such a good jumper.

These bugs express perfectly the oscillation between the gruesome and the delightful in Circus Wols. A torment for the prisoners, Wols turned them into charming performers who entertain the public, assisted by advanced imaginary technology. The sight is definitely gruesome at first. A human-scaled flea holding a fan and an umbrella and scurrying across an arena is hardly delightful, especially for a generation familiar with David Cronenberg's movie The Fly (1986). Wols was obviously not familiar with the latter but he well knew Franz Kafka's The Metamorphosis, the tragic story of a man turned into a life-sized bug (Kafka 2009). Kafka's focus on the trivial absurdity of life frequently came to mind to the undesirable foreigners who were incarcerated at Milles. Their confinement was a Kafka story come to life: many of these men had lived in France for years or had fled the Nazis; all of them were anti-Nazi, but as German citizens, they were suddenly declared a danger for France, and had been forcibly confined and isolated like the giant bug in The Metamorphosis. We know that Kafka's name circulated among the prisoners (Paire 2013, p. 65). Shortly after his liberation, Wols was reading Kafka and took notes on the edition established by Bernard Groethuysen (Wols, fund Iliazd 1940-1944, 3882). From a letter delivered to his wife Gréty in January 1945 by a doctor practicing in Lyon, we learn that the artist was searching for his copy of Kafka which he thought he had forgotten at the doctor's office (Wols, fund Iliazd 1940-1944, 3906). ${ }^{7}$

In Circus Wols, the insects are often anthropomorphic, as illustrated in The Circus; Simultaneous View and projection by the figure with the stinger enlacing, and seemingly aspirating, the sleeping man. The long hair and the breasts suggest feminine attributes, although the gender is not clear. In the same drawing, the inscriptions " $\mathrm{H}$ " and " $\mathrm{I}$ " which appear beside the long-haired figure facing the giraffe, may refer to "homme" and "insect" (human/insect). Another anthropomorphic insect performs at the center of The Circus I Adore, combining, as we have pointed out, the physiological aspects of a flea and a woman.

Kafka's abject, metamorphosed human comes to mind again. However, Wols's attitude towards insects was far from negative. In fact, the artist loved insects. In the very first pages of the Circus Wols manuscript, he specified that his circus could be a "ZOO (among others a ZOO of insects and anthropods)" (Van Damme 1985a, p. 21). ${ }^{8}$ One may wonder what these "anthropods" are. Is the word "anthropod" just a misspelling of "arthropod"? Or is it a purposeful contraction of the two words? The word is spelled correctly in the drawing Circus Wols and the neologism is used in other aphorisms. It appears in an undated poem which directly calls into question the superiority of humans over insects, and declares the "anthropods", may be a new superior species of human/insect hybrids:

\footnotetext{
7 “Non, ce n'est pas chez moi que vous avez oublié 'Kafka'. Je m'en serais aperçu après votre départ et vous l'aurez (sic) renvoyé".

8 "Circus Wols peut être p. Exemple: [ ... ] ZOO (entre autres ZOO d'insectes, d'anthropodes".
} 
it is possible that god prefers flies

to humans

the anthropods are technically superior

than humans

the day when a butterfly became beautiful

it fulfilled its task

it is dubious that one day humans

will reach the level of wasps. ${ }^{9}$ (Van Damme 1985a, p. 196)

In all cases, Wols seems to find the insects more sympathetic and more reliable than humans. Other aphorisms reiterate the comparison, privileging the arthropods (Van Damme 1985a, pp. 197, 203). If Circus Wols has a gruesome Kafka-inspired dimension, reflecting the forced promiscuity of prisoners and insects, it also has a humorous, more positive, and unexpectedly delightful side. Beyond the originality it brings to the show, the "anthropods"-perhaps standing in for the men of the Camp des Milles-are distinguished from the humans who assaulted their fellow men in the name of the purity of the race, an implicit reference to Nazi ideology. By definition, the hybridization of humans with insects annihilates the very concept of purity. Moreover, it suggests a more dynamic dialogue with other living forms, a vitalist fulfillment of humanity beyond the limits of an autonomous and stable humanist self.

\subsection{Between Humanist Utopia and Rejection of Humanism}

Circus Wols oscillates between utopia and dystopia. It prolongs avant-garde social utopias because it aims to educate a wide audience through art and render cutting-edge technology accessible for wide enjoyment (Mehring 1999, p. 19; Slavkova 2018, pp. 339-42). From this perspective, it is a humanist project nurturing the hope that by injecting art and culture into all the spheres of life, via a popular artistic experience, the artist would become the demiurge of a better world. In other words, it expresses Wols's belief in the transformative potential of art and the leading role of the artist who stands as an insightful medium blessed with unlimited freedom. The paradigm is that of the modernist avant-gardes convinced that their mission is to lead humanity to a better future through art. ${ }^{10}$ A letter to collector Pierre Lévy dated June 1943 confirms that Wols had not completely lost this faith: "you know as well as me that we live in a magnificent but funny epoch and I think that change is close" (Van Damme 1985c, p. 12). ${ }^{11}$

However, Circus Wols simultaneously thwarts the underlying utopian paradigm because it is fundamentally distrustful of grand ambitions and discourses. On 7 September 1940, while he was at Milles, Wols noted in his description of the project's structure: "remember Frobenius. The matter of delusion of grandeurs" (Van Damme 1985a, p. 23). Patrycja de Bieberstein Ilgner has demonstrated the profound influence of anthropologist Leo Frobenius on Wols during his youth. Frobenius was a family friend and a self-taught scholar whose off-track academic career appealed to the rather asocial and rebellious Otto Schulze (De Bieberstein Ilgner 2013, pp. 69-71). Like Wols, Frobenius was fond of animals and zoos; his grandfather, the physician and zoologist Dr. Heinrich Bodinus, became the director of the Berlin Zoo (p. 72). After carrying out extensive research in Africa and studying prehistoric art, Frobenius was one of the first scholars to cast into question the superiority of the white "race" and of Western culture. This first and foremost "delusion of grandeurs" had a long-lasting

9 "il est possible que dieu prefere [sic] les mouches/aux hommes/les anthropodes sont techniquement superieur [sic]/a [sic] l'homme/le jour [lorsque] un papillon a été beau/il a accompli sa tache/il est douteux que l'homme arrivorat [sic]/au niveaux [sic] des gueppes [sic]". Claire Van Damme's transcription systematically designates anthropode as a mistake but as explained above, I have not followed her in this choice.

10 There are numerous publications on the treating of that subject. Eric Michaud offers an insightful reflection on the artists as the New Man in his collection of essays Fabriques de l'homme nouveau (Michaud 1997).

11 "Pour le reste vous savez aussi bien que moi qu'on vit dans une époque magnifique mais drôle et je pense que le changement est proche". 
impact on Wols. While in Dieulefit, he wrote that the white race had not produced anything great besides Bach (Wols, fund Iliazd 1940-1944, 3876). ${ }^{12}$ In another text, an undated poem that Wols himself translated into English, one can read that "Beethoven didn't understand the rites and the drums of Zulus" (Van Damme 1985a, p. 202). He thus put the great European composer on the same level as the Zulu drums (a culture he knew through Frobenius, who carried out extensive research in South Africa); he even seems to elevate Zulus above Beethoven, who cannot understand their drumming.

Doubtlessly, Frobenius's thought and research shaped Wols's critique of Western culture and its inherent racism but the artist was also aware, thanks to his acquaintance with the group "Octobre", of the virulent anti-Western stance and interest for the so-called "minor" cultures expressed in the dissident surrealist journal Documents (Allain 2009, pp. 24-30; Bois and Krauss 1996, p. 132). Leo Frobenius himself wrote for Documents (Frobenius 1930) which regularly published articles praising African art and culture, denouncing its condescending cultural appropriation by the Europeans. Among the authors, we find the writer and art historian Carl Einstein, the writer and founder of Surrealism Michel Leiris, and the ethnologist Marcel Griaule (Einstein 1930; Griaule 1930; Leiris 1930). Plus, Documents held a "critical dictionary", published by installments, which questioned and criticized the universal pretensions and superior values of the West. In the entry "Civilization" for instance, Leiris compared the "dusty" Western civilization to a withered, fake, and polite show destined to a jaded public, a show which had lost any liberating or revolutionary potential (Leiris 1929, p. 221). As we are going to see, similar ideas subtend Circus Wols.

Wols's unfair absurd imprisonment during World War II, the terrible war itself, reinforced the artist's disillusionment with his own white European civilization. The notes for Circus Wols mention twice the equivalence "cemetery=civilization" (cimetière-civilisation) (Van Damme 1985a, pp. 34, 39). The very choice of the circus reflects a loss of faith in the grandeur of art, in line with Leiris's above-mentioned dictionary entry. Christine Mehring has argued that the circus was also in line with the populism of the avant-gardes' total artwork, but its entertaining aspect and its artifice undermined the effects of its existential alienation (Mehring 1999, p. 19). In other words, the banality of the circus and its immersive visual technologies tend to weaken its political impact, obliterating the utopian expectation of transforming the individual mindsets and the social order. Eventually, Circus Wols echoes the artist's thoughts on the banalization of avant-garde strategies and the weakening of their impact, a critique and an exploration of the limits of the modernist aesthetic project (p. 19).

It is unlikely that Wols was fully aware of the larger cultural and historical implications as well as the virulent contestatory nature of his project at the time of his interment. It is very likely, however, that the violent shock of his imprisonment and the journey through multiple camps reinforced Wols's doubt in the humanist credo that art and culture would make the world a better place. The Camp des Milles certainly played an important role in the maturation of Wols's critique of art as a revolutionary and civilizing weapon, because a great number of creators were imprisoned there. Some of them, like the Surrealist Max Ernst, were prominent members of the revolutionary avant-garde. Their isolation and disempowerment behind the narrow brick walls, the ghastly underground performances fueled by alcohol at Die Katakomben, and the pervasive feeling that art was made to cheat on anguish and death, must have shaken Wols's faith in the power of art.

Wols's circus affirms his disillusionment with art but simultaneously tends to resist this disillusionment, partly because the artist had no other choice while struggling to survive morally and physically. The paradox is palpable in the Circus Wols papers. The same sheet from 7 September 1940 which evoked Frobenius and the "delusion of grandeurs", simultaneously claimed the artist's total control over his project: "control, analysis, synthesis by me" of "the work, the material, the milieu, the realization, the success, the drawings, etc." (Van Damme 1985a, p. 23). ${ }^{13}$ The paradox is illustrated

12 "Sauf Bach la race blanche n'a pas encore produit grand chose".

13 "Le control (sic)/analyse/synthèse de moi-même du travail, matériel/milieu/réalisation/succès/dessins/ ... " 
again in the drawing Circus Wols where a miniscule figure, the artist himself as circus impresario, is lying on a bed in a tiny studio dominating the arena and the public. There is a bottle by the bed and he seems to be sleeping. Though he occupies a superior situation, the artist's vulnerability-suggested through alcohol, sleep, and diminished scale-is palpable; it echoes the persistent desire to orchestrate the artwork despite the overwhelming sense of disempowerment and loss of control.

The "delusion of grandeurs", especially in art, continued to haunt Wols. This concern was even amplified upon his return to Paris where he exhibited regularly in association with the rising post-war abstraction school (Mehring 1999, pp. 14-15). Thanks to the support and connections of influential personalities-Henri Pierre Roché, Pierre Lévy, Jean-Paul Sartre, Jean Paulhan, who discovered his art during or just after the war-Wols held two one-man shows: from 21 December 1945 to the end of January 1946, then 22 May-17 June 1947, at the prestigious Drouin gallery situated on the square Vendôme next to the Hotel Ritz. A letter from Henri-Pierre Roché received one week before the opening asserts Wols's disappointment with the circumstances of his first solo exhibition, and by extension with his epoch. Roché wrote: "I totally agree with you on the paltry value of our epoch-but we are 'inside' and we are dependent on the law of 'supply and demand'" (Van Damme 1985c, p. 92). ${ }^{14}$ Let us be reminded that two years earlier, Wols had written to another collector, Pierre Lévy, qualifying their epoch as "magnificent but funny" (Van Damme 1985c, p. 12). In 1945, the artist was less optimistic, and his first experience with the art world turned out to be so conflictual that he hired a lawyer to defend his interests against René Drouin (Van Damme 1985c, p. 93).

This disillusionment with art is sensible in Wols's aphorisms as well. Referring to human actions, and implicitly to artistic production, these short texts, which represent a considerable amount of Wols's writings, negate the possibility of transformative art, and more generally of any grand discourse. The artist's distrust of grandiloquence grew in proportion to his isolation and misery in Dieulefit, where he was once again threatened as a stateless "apatride" after German troops took control of the Free Zone. One aphorism conceived there testifies explicitly to Wols's definitive dismissal of great discourses (Figure 7). Here, as in the greater part of the archives, the writing is difficult to decipher and departs in all directions on the page. One of the two inscriptions (on top in our illustration) reads: "Before informing the students at school about the incidence of the public dangers such as tuberculosis, syphilis and plague, we should draw their attention to bigger dangers such as great achievements, ambitions and politics and [unreadable]." (Wols, fund Iliazd 1940-1944, 3878; Slavkova 2018, pp. 341-43). ${ }^{15}$

Several undated aphorisms - very probably conceived in Dieulefit or in Paris after 1945 because they convey a similarly deep distrust of humans as the previously cited text-confirm this stance by making clear allusions to art. For instance, one of Wols's most cited aphorisms, "one tells one's little worldly tales through little pieces of paper" (Van Damme 1985a, p. 236), ${ }^{16}$ may refer to both Wols's drawings and writings as the artist worked on small formats, often literally on found pieces of paper, like Figure 7. Other aphorisms more explicitly refer to the failure of art: "let sleep/Beethoven/ Adam and Ev[a]/yourself and yo[ur]/friends Marx/ and Picasso. Leonardo/ mankind is bluff" (185, originally in English). Or yet another one: "Human, have you ever seen a zebra make love? It changes the sheets. Art and literature goof up. The best we kill." (Van Damme 1985a, p. 211). ${ }^{17}$ The passage was reworked into a longer poem on another "piece of paper" (p. 212). Wols named a few artists who were "honored" to be "killed by society faster than cattle": Van Gogh, Modigliani, Artaud, Novalis, Mozart, Shelley. He significantly included himself in the list.

14 “Je suis complètement d'accord sur la piètre valeur de notre époque-pourtant nous sommes 'dedans' et nous dépendons de la loi de 'l'offre et de la demande'".

15 "Avant de parler aux élèves des écoles [ ... . . aux danger publiques comme la tuberculose, la syphilis et la peste, il faut attirer leur attention sur les dangers les plus grands comme les exploits, les ambitions et la politique et les [... ]."

16 "On raconte ses petits contes/terrestres/à travers de petits bouts de papiers (sic)". Claire Van Damme mentions the multiple citations of this aphorism.

17 “Homme, as-tu déjà vu le zébra (sic) faire l'amour? Ça change les draps. L'art et la littérature gaffent. Le meilleur on tue." 


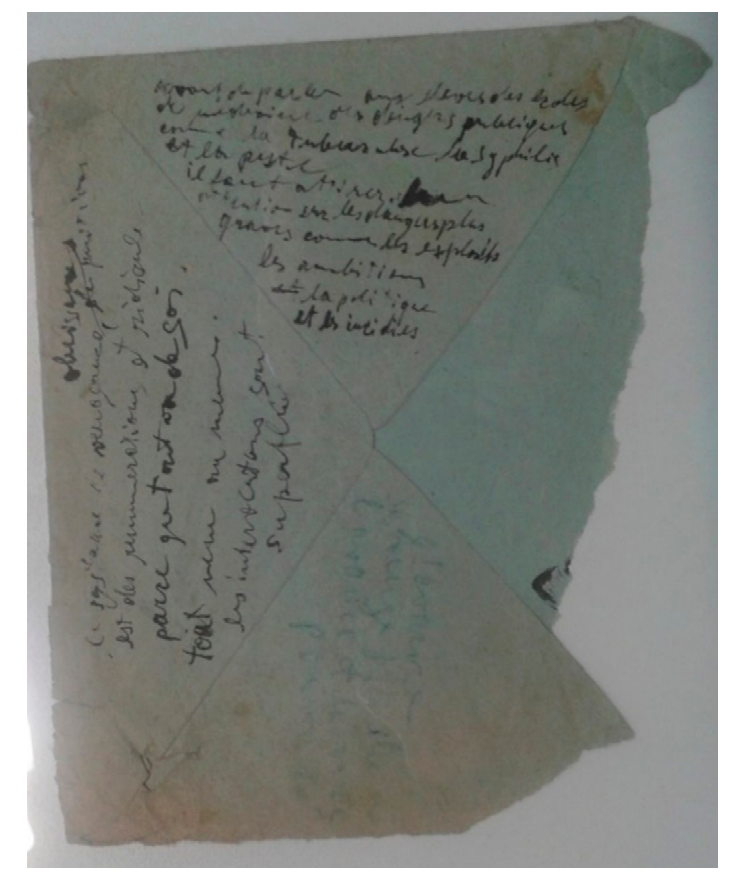

Figure 7. Dieulefit, 1941-1944, Archives Wols, fund Iliazd 3878. Bibliothèque Kandinsky/MNAM. (C) Adagp, Paris, 2020/Courtesy Bibliothèque Kandinsky.

His disappointment with art is paralleled by an even more violent rejection of humanity as a whole. With biting irony, Wols repudiates any pretense of human superiority, and often refers to humans as "bipeds" (Van Damme 1985a, pp. 117, 186-88). He bitterly rejects categorizations and hierarchies established by men, and more specifically those established by the humanist tradition. One poem, translated into English by the artist, expresses this skepticism. It questions the hierarchy of species, "races", and cultures; casts doubt upon mankind's domination of the universe; and underscores the isolation and limits of human perception, as well as the relativity of human theories and acts:

Man thinks only for and by himself,

creating his own God

loving, hating himself,

unable to take the universe

but always pretending

by all ways of knowledge

that he and sea souls are old friends.

Beethoven didn't understand the rites

and the drums of Zulus

We barely heard the birds,

and vice-versa.

So man will never learn to fly like birds, swim like fish,

except in intimate reality.

he cannot understand the absolute though he

must

love what has captured him beforehand.

(theris (sic) no need to act, only to [think] believe. (Van Damme 1985a, p. 202) 


\section{Wols and (Art) History: The Abhumanist Thesis}

\subsection{Difficulty to Categorize Wols in the Post-World War II Parisian Art World}

Wols's sense that grandiloquent totalizing projects and discourses were dangerous cannot and should not be separated from the immediate context of World War II, despite the fact that the artist rarely referred to concrete historical events. While he was a political prisoner at Milles or living semi-clandestinely in Dieulefit, this grandiloquence, embodied by Hitler's or Pétain's societal projects, stamped his flesh forever. He knew that their respective visions had endangered or led to the death of millions, all with the promise that mankind would thereby recover its perfection, purity, and might. So when "great achievements, ambitions and politics" were defined by the artist as more dangerous than diseases such as tuberculosis (Wols, fund Iliazd 1940-1944, 3878), he literally meant that they were mentally and physically toxic, more destructive than any germ created by nature.

As we have seen, through his own contradictions and the purposeful state of fragmentation of his oeuvre, Wols fully assumed both the incompleteness and the uncertainty of his own realizations. As a tentative Gesamtkunstwerk, Circus Wols is the most appropriate example in this sense. In its utopianism, it falls into the category of "grand discourses", but it simultaneously instantiates doubt about their necessity and feasibility. In Dieulefit, Wols thought again of his circus in contradictory terms: it is an "abstract dream (maybe feasible)" (Wols, fund Iliazd 1940-1944, 3913). As Franz-Joachim Verspohl has noted, it is logical to assume that "it was superfluous for Wols to stage manage a circus in a contemporary situation in which the whole world has become a madhouse" (Verspohl 1991, p. 62).

Circus Wols progressively disappeared from the artist's writings and drawings. Giving up the circus project may have been a way to protect his original vision from ever turning into something unequivocally grotesque (Verspohl 1991, p. 62). Distrustful of human nature and of the notion of civilization, Wols was probably looking for an art which would express his growing conviction that his activity was not human (Wols, fund Iliazd 1940-1944, 3871). ${ }^{18}$ In Circus Wols already, humans tended to be eclipsed by non-human performers; arthropods and "anthropods" occupied the center of the arena and, by extension, of the world. A few years after the circus, humans, and even "anthropods", disappeared entirely from Wols's drawings, gouaches, and paintings. Undefined organic abstract forms would dominate his art until his death.

At the first Drouin gallery show in late 1945, not a single work contains human figures, although allusions to human body parts and organs persist. The catalog was conceived carefully by Wols while he was still living in Dieulefit (Wols, fund Iliazd 1940-1944, 3862-66). The artist meticulously selected a series of short quotations that were paired on double pages with reproductions of his drawings (Figure 8).

The drawings themselves were meticulous, as well, a meticulousness underscored by their small scale. The work we see on the double page in Figure 8, entitled The Town (1944-1945, ink, watercolor, gouache, today in private collection; reproduced in Wols 1989, p. 236), is roughly the size of a postcard $(9.8 \times 16.2 \mathrm{~cm})$. The exhibition catalog is a bit smaller in width $(10.2 \times 13 \mathrm{~cm})$, and is reproduced here at actual size so that the drawing appears just slightly smaller than its actual dimensions. One can imagine the care with which Wols worked these refined, precise lines to form the complex grid that intersects with no less complex entangled perspectives. There is some sense of structure but it is thwarted by the almost organic profusion of lines. The alignment of verticals may recall the masts of the ghost ships at Milles. In any case, there is no human presence; the town is a self-contained organism, in which growth and entropy overlap. The matching citations cast a doubt on human superiority or the possibility of a harmonious community and emphasize the unreliability of human judgment. They point to the modest place of humans in the universe. Lautréamont's misanthropic Dirges of Maldoror (Chants de Maldoror), one of Wols's favorite texts, is cited twice.

18 "Mon activité ne me semble pas humaine". 


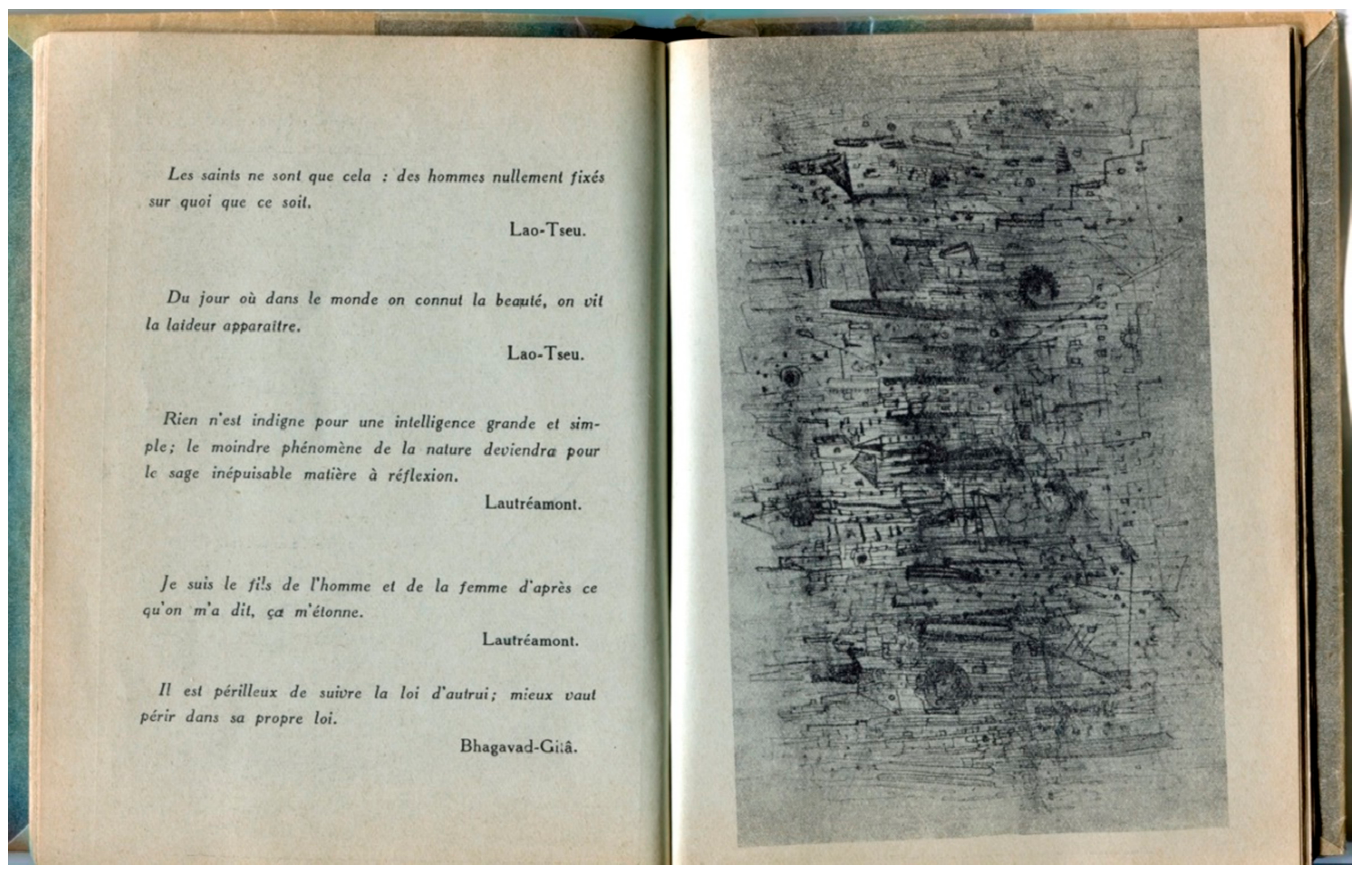

Figure 8. Double page from the catalog Wols, gallery Drouin, 1945. Paris: Jean Belmont/Galerie Drouin [np]. Collection of the author.

By its small size and fragmented content, the Drouin catalog, the only book project that Wols realized in his life, expressed his conviction that humankind was irrelevant and should not be the dominant subject in art. It prolonged the doubts initiated in Circus Wols to the point of obliterating any utopian dimension. After confronting imprisonment as well as total isolation and famine during the war years, Wols confronted the actual "circus" of the art world. This only disillusioned him more and compounded his doubt about the role of art in society. In a short text written in December 1945 after the opening of his exhibition, he commented ironically on his gallerist: "we should have a bit of esteem for René Drouin for having mocked /with these watercolors shown in exaggerated aquariums/his clients who are snobs and myopic" (Van Damme 1985a, p. 102). ${ }^{19}$ The biting humor and the distance from the meaningless agitation of the art world remained the artist's only option. Wols himself described metaphorically his "flight" from the impeccable upper-class Vendôme square to peripheral bistros, alluding self-ironically to his alcoholism (p. 101). ${ }^{20}$

Despite his purposeful flight, Wols became one of the most important Parisian artists in the post-war period. His disbelief in the modernist paradigm and the difficulty to classify him stylistically did not hinder the recuperation of his art by various, mostly abstract, tendencies claiming to prolong and renew the avant-garde as part of a humanist effort to redeem art and culture after the Second World War. Wols's untimely death in 1951 only accelerated the process and contributed to his mythification. He was claimed by "Informel", "Tachisme", and "Abstraction lyrique"; Michel Tapié and Jean-Paul Sartre lauded his works. In his book Au-delà du tachisme (Beyond tachisme), the abstract painter and personal acquaintance Georges Mathieu mentioned Wols as a chronological landmark in post-war artistic production (Mathieu 1963, pp. 31,73). In the eyes of the influential German art historian Werner Haftmann, the role played by Wols in such a crucial art world venue as Paris proved the resistance of

19 “[ ... ] ayons un peu d'estime pour René Drouin pour s'avoir moquer (sic)/avec ces aquarelles presentés (sic) dans des aquariums exagérés/de sa client elle (sic) des snobs et de mioppes (sic)". The works were presented in illuminated vitrines which Wols compares to aquariums.

20 "en effet ces derniers mois on a vu 2 ou 3 fois passer dans cette impeccable architecture l'ombre d'un petit homme presque invisible et quasi chauf (sic). Mais toujours il s'enfuit tout de suite pour rejoindre les quartiers des bistrots". 
the German spirit against the national-socialist ideology (Haftmann Werner 1964, p. 463; Mehring 1999, pp. 10-11).

The climax of Wols's glory was the comparison with Jackson Pollock (1912-1956) who had become a star in the US thanks to his dripping technique described in a lengthy article in the popular Life magazine in 1949. Throughout the 1950s, many examples testify to the parallel established between the two artists. In a diagram drawn by Michel Tapié and published in the catalog of the show Véhémences confrontées at the gallery Nina Dausset in 1951, Wols and Pollock, whose works were displayed simultaneously for the first time, respond to each other on the vertical axis to the left, in the section called "Amorphics" (Figure 9; Tapié 1951). A year later, art critic René de Solier stated, without any proof, that Wols's influence on Pollock was self-evident (De Solier 1951-1952, p. 30). In the beginning of the 1960s, his colleague Pierre Restany wrote that a mythic Wols responded to the mythic Pollock on the other side of the Atlantic, the two artists having in common their great art and the speed with which they burnt through their lives (Restany 1962, p. 53). General art histories and vulgarized books on abstract art perpetuate the comparison (Haftmann et al. 1971, p. 18; Vallier 1998, p. 247). Wols somehow became the embodiment of the vitality of the post-war Parisian scene and its ability to confront the novel vigorous art emanating from New York.

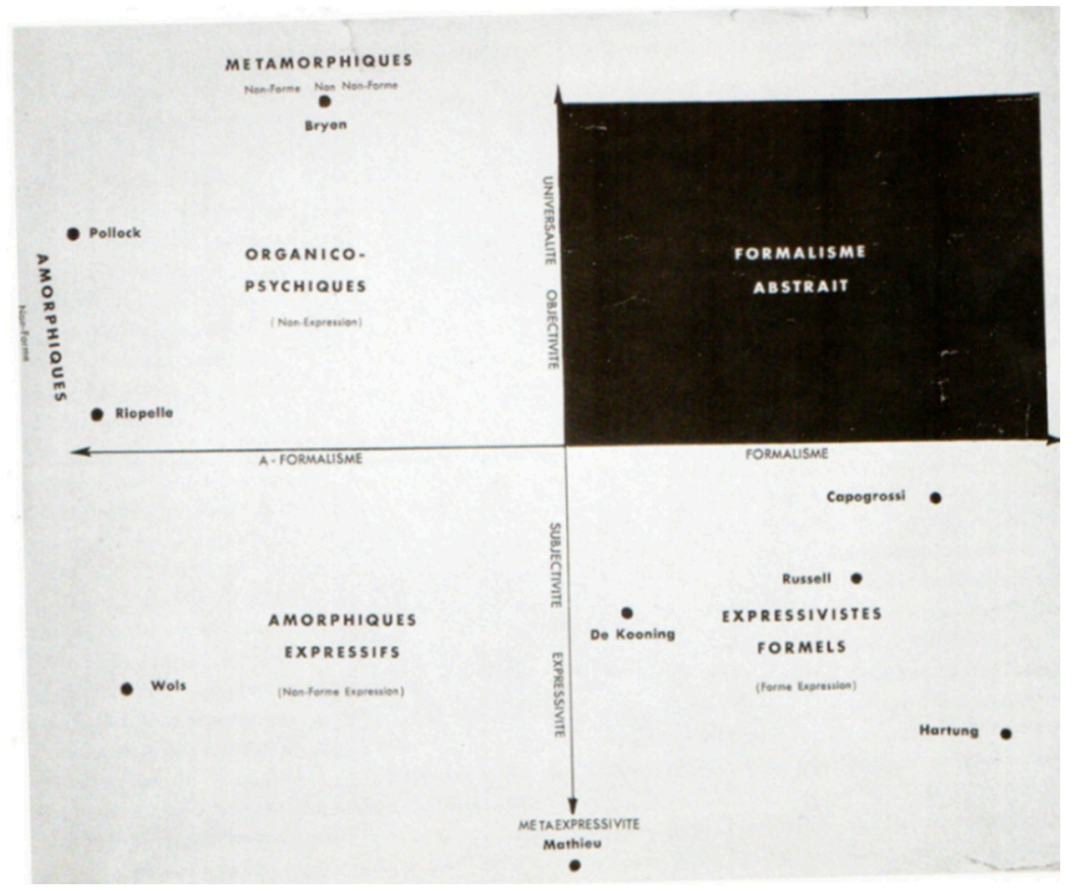

Figure 9. Flyer for the exhibit Véhémences confrontées, gallery Nina Dausset, 8-31 March 1951. Archives Camille Bryen. Courtesy Fondation de France.

Wols's most notorious champion was the philosopher Jean-Paul Sartre (1905-1980). The two men knew each other fairly well and collaborated on several projects. Wols illustrated Visages (Sartre 1948a) and Nourritures followed by extracts of La Nausée (Sartre 1948b), and his plates convey a certain complicity with Sartre's theories (Verspohl 1991, pp. 58-59, 64-65). Sartre was particularly oriented towards the visual arts and his existentialism offers indeed a framework to interpret Wols's art (pp. 58, 63-66). However, Sartre's interpretation of Wols is imbued with grandiloquence incompatible with the artist's work. To him, Wols was a doomed visionary, a major example, together with Paul Gauguin, of his theory that self-destruction of the artist's flesh is the only road to an accomplished art (Sartre 1964, pp. 409-10; Bauer 1969, pp. 144-45; Slavkova 2011, pp. 96-100). However, as we have seen, Wols's diminutive pieces of paper counter the idea of art as tragic accomplishment, and the artist never spoke of his alcoholism as a transcendent psychic state (Slavkova 2011, pp. 88-89). He attempted 
several detoxifications, all in vain. Their failure was consistent with his circumspection towards the medical establishment which paralleled his distrust with grand philosophical discourses (pp. 101-2).

It is important to recall that the authors mentioned above emphasize almost exclusively Wols's late abstract works (Mehring 1999, p. 10; Slavkova 2011, p. 101). In the 1950s and early 1960s, Mathieu, Sartre, De Solier, or Restany, among others, wrote typical-for-the-period texts full of pathos. In the mid-1960s, when more concrete and objective art forms such as Pop Art and New Realism emerged, both abstraction and the lyrical art criticism that accompanied it were diminished in status. Wols's work did not fit the dominant paradigm anymore and he was put aside. Moreover, as art historian Serge Guilbaut has established, Paris was increasingly purposefully downgraded to become the shadow of New York in a period when the Cold War determined cultural politics (Guilbaut 2008). Wols, the "French Pollock", became a collateral victim of this shift. The exclusive focus on his abstract works whitewashed Wols's earlier figurative watercolors and gouaches, and above all, his photographs (Mehring 1999, pp. 11-12). The meteoric mythification of Wols's abstract works devalued the diversity, complexity, and historical relevance of his oeuvre as a whole. Litigation related to authentication, as well as difficulties accessing the archives held by Gréty's second husband, Marc Johannes, added to this obfuscation of Wols's project. ${ }^{21}$

\subsection{Wols and Abhumanism}

Even though Wols was an utterly singular creator, his feeling that his art was not human recalls the precepts of abhumanism, a largely overlooked and deliberately downplayed (Guérin 1999, pp. 10, 24; Toloudis 1980, pp. 109-11) philosophical literary trend which emerged in his neighborhood of Saint-Germain-des-Prés after the Second World War, led by writer and playwright Jacques Audiberti (1899-1965). Already determining the worldview of several novels written in the late 1930s, but published in the 1950s (Marie Dubois (1937/1952), Les Médecins ne sont pas des plombiers (1937/1949), Infanticide Préconisé (1937/1958), Carnage (1939/1942) $\left.{ }^{22}\right)$, established as a specific term just after World War II, and extensively theorized throughout the 1950s by Audiberti, abhumanism was contemporaneous with Wols's work. It was ignited by the same global historical events and the same immediate context. In Paris after the Second World War, Audiberti, like Wols, was struggling to define the place of the creator-poet or visual artist-in society (Toloudis 1980, p. 32). Like Wols, Audiberti's stance was dystopian but penetrated by a sort of immanent vitalism (pp. 28-29).

As far as we know at the actual stage of research, Wols never mentioned abhumanism, nor did he cite Audiberti; similarly, the latter never referred to the artist. ${ }^{23}$ They were, however, virtually connected through the figure of poet-painter Camille Bryen who was a very close friend of Wols's (he published a text in the Drouin exhibit catalog, Wols 1945, n.p.) and of Audiberti's. In 1952, Audiberti's and Bryen's L'Ouvre-boite. Colloque abhumaniste, a seemingly improvised, stream-of-consciousness dialogue full of puns and absurd jokes, read like a manifesto of abhumanism (Audiberti and Bryen 1952). A consequent passage, written by Bryen-whose artistic production was as varied as that of Wols: writing, drawing, painting, prints, books, photographs-, was dedicated to Wols:

I had an old friend. I knew the schemes and rites by which he conjured his human status. He was, among the human beings I have known, the least mired in the species. He possessed a lucidity which made him discover complex techniques destined to improve the rhythm of

21 My conversations with gallerist Christoph Pudelko (1998-1999) and scholar Claire Van Damme (2011) confirmed the litigations, although their points of view were different. A few letters at the Documentation of the Musée national d'Art moderne (Centre Pompidou) also discreetly testify to the conflict. The delicate nature of this question makes it uneasy to treat in publications. The litigations are mentioned in an article accounting for the sales of Wols's archives in 2011 (Koldehoff 2011 ).

22 Incredibly prolific, Audiberti had a hard time publishing his novels and poems at first. The manuscript of Infanticide préconisé remained in the drawers for almost twenty years (Fournier 2020, p. 120).

23 I am grateful to Bernard Fournier, the president of the Association des Amis d'Audiberti, who, having worked extensively on Audiberti's correspondence archive at the IMEC (Caen) in view of the publication of his recent biography (Fournier 2020), confirmed this information. 
his life, and superstitions which enabled him to function more as a vegetal machine than a citizen. He was in the whirlwind, humanity bored him. ${ }^{24}$ (Audiberti and Bryen 1952, p. 119)

Bryen recognized in his friend a capacity to break the boundaries of humanity which was, as we saw previously, a state Wols desired himself. The sheet mentioned in the beginning of this article, where Wols claims that his art was not human-maybe part of a book project as the note at the bottom indicates - contains other statements evidencing his not being "mired " in the species, as Bryen put it (Figure 10; Wols, fund Iliazd 1940-1944, 3871). Here, besides "My activity doesn't seem human to me", we also read, "I am a victim of the natural history sort", then, "I am a microbe, maybe observed through a telescope by the inhabitants of an atom or by the ministry of the Milky Way", then, "There is matter which is illusory to man, an essence without name which penetrates. We are a sub-form". The desire to burst beyond the human underlies the watercolors for Circus Wols where fleas overshadow humans, humans fuse with bricks, and hybrids associate their bodies with different natural kingdoms. Wols's subsequent gouaches and oils mingled human organs, fossils, insects, plants, rocks, and microorganisms (Wols 1989, pp. 175, 177, 274, 276). His photographs—namely his still lifes of the late 1930s featuring vegetables, meat, dead rabbits, and chicken (Mehring 1999, pp. 72-73, 76-79) - emphasize the raw triviality of human existence and the inherent cruelty of mankind feeding on flesh (although Wols loved meat and died of food poisoning after eating rotten horse meat (Van Damme 1986, p. 14).

Raw flesh, human abjection, cruelty, and triviality, as well as the suggestion to cut short the humanist grandiloquence and deflate the human ego in order to open a cosmic becoming for the long-inhibited humanist subject, are topics tackled by abhumanism, as well. Audiberti's novel Marie Dubois is a good example of this: after falling in love with a dead woman, the protagonist, an insignificant and rather weak police officer, becomes an outlaw and discovers his unsuspected "non-human" powers, connecting himself to the energy of the universe (Audiberti 1952).

For Audiberti, like for Wols, reflection on the limits of humanism was determined by his poor opinion of his historical epoch, and by his frustration with the artistic/literary circles in Paris (Guérin 1999, pp. 22-23). Though unlike Wols, Audiberti didn't experience in his flesh the horrors and absurdity of World War II in a camp, the war bolstered the writer's sense of the inanity of Western civilization and the failure of its founding paradigm-humanism. The term "abhuman" was directly related to the war as well. It appeared for the first time in 1946, in Audiberti's article "Guéridons abhumains" (Abhuman Café Tables ${ }^{25}$ ). Audiberti associated it with the novel La Giostra di Michele Civa (The Merry-go-Round of Michele Civa) by the Italian writer, journalist, and painter Beniamino Joppolo (Audiberti 1946, pp. 33-34). Shaken by the horrors of the Second World War, Joppolo devised the story of the soldier Michele Civa who, in an access of folly but also in search of redemption, massacres innocent children playing near a merry-go-round. Joppolo's point was that the ineffable brutality of war could only be understood and redeemed if brought to an unbearable climax, pushing humans to assume and ponder their bestiality.

In 1955, Audiberti published a collection of essays under the title L'Abhumanisme, suggesting how the new term might be applied to poetry, philosophy, love, science, language, politics, history, and painting. The author situated abhumanism in a broader literary and philosophical tradition and related it to the historical and political context of the two world wars. In the first essay, entitled "The War", he qualified the recent conflicts as both the logical outcome and death knell of humanism (Audiberti 1955, pp. 7-28). Since it stands for the extreme refinement of diplomatic and military strategy, war is, Audiberti argued, the very embodiment of the humanistic idea of rational perfectibility, "it is even

24 “J'avais un vieil ami. Je connaissais les manigances et les rites par lesquels il conjurait son grade d'homme. Il était, parmi les êtres que j'ai connus, le moins enfoncé dans l'espèce. Il avait une lucidité qui lui faisait découvrir des techniques complexes destinées à améliorer le rythme de sa vie, et un ensemble de superstitions propres à le faire fonctionner plus en machine-plante que comme citoyen. Il était dans le tourbillon de l'air, l'homme l'ennuyait".

25 For the sake of clarity, the titles translations are literal. 
the perfection of humanity" (pp. 19-20). War also demonstrates how humankind fabricates grand discourses to justify brutality (p. 26).

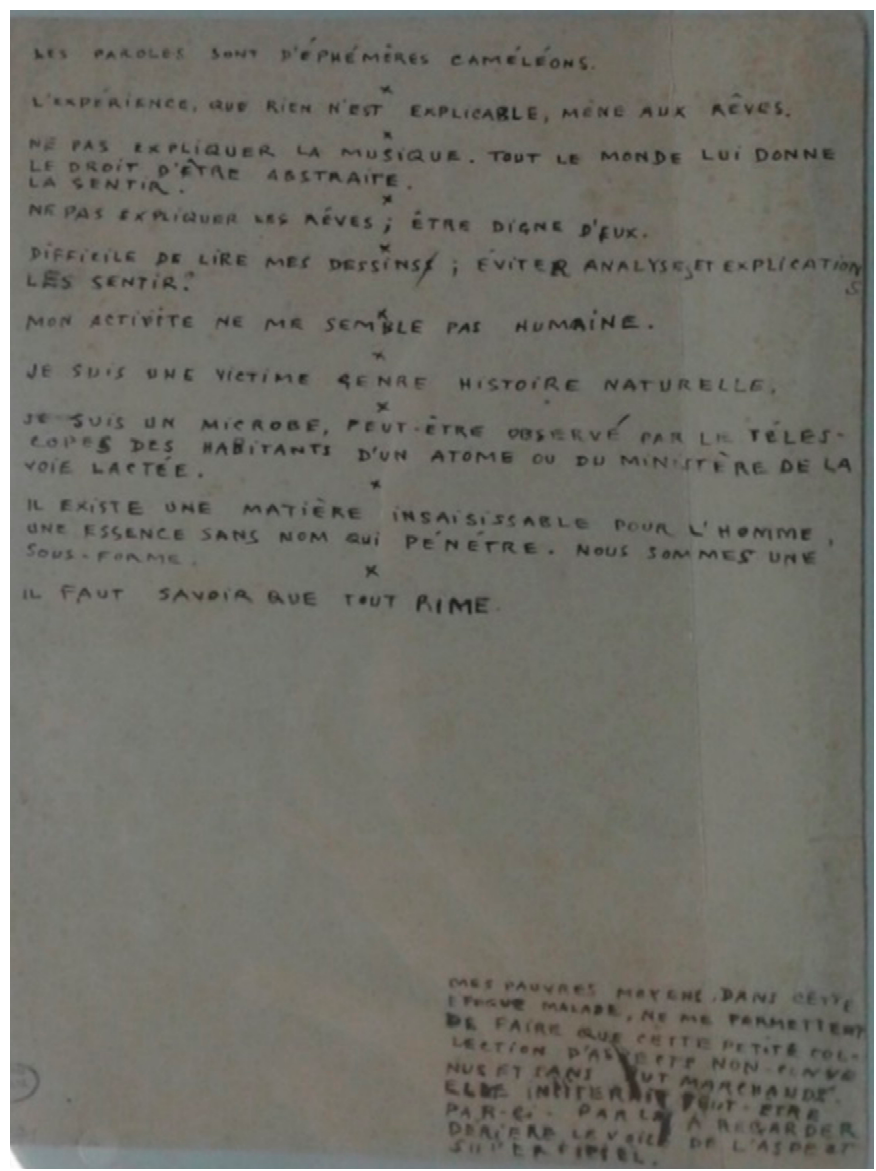

Figure 10. Aphorisms/Project for a book? Dieulefit, 1941-1944. Archive Wols, fund Iliazd 3871, Bibliothèque Kandinsky/MNAM. (c) Adagp, Paris, 2020/Courtesy Bibliothèque Kandinsky.

The aftermath of the Second World War marked the birthdate of abhumanism but, as we said earlier, Audiberti had been developing abhumanist ideas in some of his 1930s novels. He went even further back in time and explicitly rooted his concept in the crisis of values caused by the World War I catastrophe. In a 1962 stenotype, he stated that the 1914-1918 conflict was the fateful cleavage for Western humanist culture (Delandes 1964, p. 43). The rationalized slaughter made it impossible to educate or be educated as before:

Schoolchildren knew by heart the names of the forty members of the academy, just like the names of the ministers of successive cabinets. Kipling, d'Annunzio, Tolstoy structured our international literary universe. There was a sort of coziness and security in the knowledge that a little schoolchild might acquire of the Grand Siècle, the Middle Ages, Antiquity; and all due to an organization of the universe that was the culmination of the preparatory stages of humanity. That sensation of the absolute modern world is extremely threatened today. I would even say that it no longer exists. ${ }^{26}$ (Delandes 1964, pp. 42-43)

26 “les écoliers des sections littéraires connaissaient par cœur les noms des quarante académiciens, de même d'ailleurs que les noms des ministres des cabinets successifs. Kipling, d'Annunzio, Tolstoï structuraient l'univers littéraire international. Il y avait donc une sorte de chaleur et de sécurité dans la conscience qu'un jeune écolier pouvait avoir d'une organisation enfin réussie de l'univers, après les âges préparatoires, à savoir le grand siècle, le Moyen Âge et l'Antiquité. Cette sensation du monde moderne absolu est aujourd'hui extrêmement menacée. Je crois même qu'elle n'existe plus". 
According to Audiberti, the humanist dream of a harmonious order confident in the ascension of the cultivated civilized European collapsed with the First World War. That debacle was deepened by a second massive conflict, accompanied by a minutely planned genocide, erupting within twenty years of the first in the self-proclaimed heart of "civilization". Abhumanism, like Circus Wols, was born out of this sense of collapse; they were a reflection on the harrowing transformation of this civilization into a cemetery. Audiberti, Bryen, and Wols sought to dethrone humans as supposedly superior species thus liberating them from the weight of their outrageous pretensions for grandeur. They thought that humans should remember that their place in the universe was infinitely small, that humanity was a very recent element in the evolution of the Earth and the cosmos:

What is abhumanism?

It is man finally letting go of the idea that he is the center of the universe.

What is the purpose of abhumanism?

To diminish the sense of our eminence, of our dominion and excellence in order to restrain in the same time the sacrilegious gravity and the poisonous stinging of the insults and pains we are suffering. (Audiberti 1955, p. 35)

Rather than recapitulating the so called great human achievements, the only viable option for humans was to assume their status of "terrestrial bipeds" (Audiberti and Bryen 1952, p. 154)—indeed, Audiberti and Bryen also used this term-and subsequently their raw vitalism. For these men, art was an expression of this vitalism needing no justification, no noble resolutions, that humanist rationality was unable to circumscribe.

\section{Conclusions}

Considering Wols in relationship to abhumanism does justice to the complexity and historical insightfulness of his oeuvre as a whole, and of the project Circus Wols, in particular. Wols's apparent outlier status during his lifetime may thus be interpreted as a strong engagement with the future of art, a valid reflection on the relevance of European modernism after the two world wars. Wols resolutely rejected the model of the avant-garde, as well as that of progressive Hegelian history, assuming simultaneously the weight of the past and the vacuity of starting at zero. Approaching Wols and his circus through this lens allows, as Katy Siegel has suggested, "to think more productively of artists who work with extreme ideas, expressions, or forms, not as pushing forward a single direction but as operating under extreme social and cultural conditions" (Siegel 2011, p. 16). ${ }^{27}$ In other words, if for Wols art remained a means, if not the only means, of dealing with the complexity of the human condition, the modernist and humanist vision of the autonomous artist anointed with absolute freedom was impossible to sustain after the two world wars and subsequent emergence of a mass consumer society.

Lastly, reflecting on Wols in abhumanist terms as the least "mired in the species [ ... ] function[ing] more as a vegetal machine than a citizen" (Audiberti and Bryen 1952, p. 119) establishes a bridge between histories of modernism and recent theories such as posthumanism which questions the place of the human in the context of global digital capitalism. Like abhumanism, posthumanism stipulates the end of the autonomous human subject as a master of the self and the world (Mahon 2017 , p. 9). It claims that there are no boundaries between the biological and non-biological, humans and objects (p. 4). It undermines the illusion of purity and theorizes a prosthetic cyborg amplifying the physical and mental self (p. 8), entailing a disruption of traditional morals, of anthropocentrism and of capitalism (pp. 8, 18-21). These ideas permeate Circus Wols. Though the exact relationship between Wols, abhumanism, and posthumanism needs to be studied in more specific terms, applying

27 Though in this passage Siegel comments on the American context, her interest in Wols along these lines is confirmed by a text published in the Bremen/Houston retrospective of Wols (Siegel 2013). 
an abhumanist reading to Wols's work does highlight the actuality of his oeuvre as a prefiguration of the essential questions of the future.

Funding: A faculty research grant from American University of Paris funded copyright for the images. AUP also funded travel for conferences where aspects of this research were confronted to the international academic community (2018-2019). The University of Clermont-Auvergne (CHEC) supported a presentation on Circus Wols in 2016 which enabled me to progress significantly in this research. The material presented in this article has benefitted from funding for archive work and interviews in the framework of the Labex project ANR REPER, Université Paris I Panthéon Sorbonne (2011).

Acknowledgments: I warmly thank the staff of the Musée national d'Art moderne/Centre Pompidou: Camille Morando, a scholar specialist of the period and documentalist in chief of modern painting, for her precious help and guidance; Anne Lemonnier, who was in charge of the drawings at the Cabinet d'Arts graphiques, not only enabled me to see Wols's drawings but shared her expertise on the artist; the staff of the Bibliothèque Kandinsky for their availability and profesisonalism. I also express my gratitude to Patrycja de Bieberstein Ilgner, supervisor of the Wols fund at the Karin and Uwe Hollweg Stiftung in Bremen for her help and the useful documentation she generously provided me with. I owe a lot to gallerist Christoph Pudelko who introduced me to the complex context surrounding Wols's work, and offered the possibility to see original documents. I also thank Claire Van Damme for our enriching conversation at the University of Ghent, and her gift of the three volumes transcribing Wols's archives which are since then available to scholars at the Library of the INHA (Paris). The president of the "Association des Amis d'Audiberti", and Audiberti's biographer, Bernard Fournier shared precious information on Audiberti's correspondence. Many thanks to him and Marie-Louise Audiberti (the writer's daughter) for embracing with enthusiasm my work on abhumanism. My gratitude also goes to my colleagues art historians Bernard Zirnheld, whose careful reading and suggestions made this text so much better, and Marianne Jacobi who encouraged me to resume work on Circus Wols for a conference in Clermont-Ferrand in 2016.

Conflicts of Interest: The author declares no conflict of interest.

\section{References}

Allain, Patrice. 2009. Jacques Baron. L'enfant perdu du Surréalisme. La Nouvelle revue Nantaise: 5. Nantes and Paris: Les Amis de la Bibliothèque Municipale de Nantes/Éditons Dilecta.

Audiberti, Jacques. 1946. Guéridons abhumains. L'âge D'or 3: 22-34.

Audiberti, Jacques. 1952. Marie Dubois. Paris: Gallimard.

Audiberti, Jacques. 1955. L'Abhumanisme. Paris: Gallimard.

Audiberti, Jacques, and Camille Bryen. 1952. L'Ouvre-Boîte. Colloque Abhumaniste. Paris: Callimard.

Bauer, George Howard. 1969. Sartre and the Artist. Chicago and London: University of Chicago Press.

Bertrand-Dorléac, Laurence. 1997. L'Euvre au camp. In Les Peintres au camp des Milles. Septembre 1939 -été 1941. Edited by Michel Bépoix. Aix-en-Provence: Actes Sud, pp. 24-27.

Bois, Yve-Alain, and Rosalind Krauss. 1996. L'Informe. Mode D'emploi. Paris: Editions du Centre Pompidou.

Caille, Béatrice, and Juliette Laffon. 2013. Bellmer, Ernst, Springer, Wols au Camp des Milles. Aix-en-Provence: Fondation du Camp des Milles, Paris: Flammarion.

De Bieberstein Ilgner, Patrycja. 2013. Wols. Retrospective. Edited by Toby Kamps. Houston: The Menil Collection, Munich: Hirmer, Bremen: Kunsthalle Bremen, pp. 68-77.

De Solier, René. 1951-1952. Wols. Cahiers de la Pleiade 13 (Autumn-Spring): 29-36.

Delandes, André. 1964. Audiberti. Paris: Gallimard.

Einstein, Carl. 1930. À propos d'une exposition à la galerie Pigalle. Documents 2: 104-11.

Foster-Matalon, Emmanuelle. 1991. Les Artistes-peintres allemands en exil à Paris 1933-1939. Ph.D. dissertation, University of Paris I Panthéon-Sorbonne, Paris, France. Unpublished.

Fournier, Bernard. 2020. Métamorphoses d'Audiberti. Une Biographie 1899-1965. Saint-Jean des Mauvrets: Editions du Petit Pavé.

Frobenius, Leo. 1930. Dessins rupestres du Sud de la Rhodésie. Documents 4: 185-88.

Fry, Varian. 1945. Surrender on Demand. New York: Randon House.

Gausmann, Angelika. 2013. Trop beau pour rester dans l'oubli. In Mémoire du camp des Milles 1939-1942. Marseilles: Métamorphoses/Le Bec en L'air.

Glozer, Laszlo. 1980. Wols Photographe. Paris: Editions du centre Pompidou.

Grandjonc, Jacques. 1999. Europe-Amérique. D’un exil à l'autre. In Varian Fry. Mission Américaine de Sauvetage des Intellectuels Antinazis. Aix-en Provence: Actes Sud, pp. 45-48.

Griaule, Marcel. 1930. Un coup de fusil. Documents 1: 46-47. 
Guérin, Jeanyves. 1999. Audiberti: Cent ans de Solitude. Paris: Honoré Champion.

Guilbaut, Serge. 2008. Postwar. On an Exposition: Tempestuous Transtlantic Culture, 1946-1956. Edited by Laurence Bertrand-Dorléac. Seminar Arts \& Société \#22. Paris: Fondation nationale des Sciences Politique, Available online: http://www.sciencespo.fr/artsetsocietes/en/archives/2206 (accessed on 17 August 2020).

Haftmann Werner. 1964. Malerei im 20. Jahrhundert. Munich: Prestel. First published 1954.

Haftmann, Werner, Jean Leymarie, and Michel Ragon. 1971. Abstract Art Since 1945. London: Thames and Hudson.

Inch, Peter. 1978. Circus Wols. The Life and Work of Wolfgang Schulze. Todmorden: Arc Publications.

Kafka, Franz. 2009. The Metamorphosis. Translated by Ian Johnston. Auckland: The Floating Press. First published in German 1915. Available online: https://www.worldcat.org/title/metamorphosis/oclc/605918681 (accessed on 17 August 2020).

Kessin Birman, Elizabeth. 1997. Moral Triage or Cultural Salvage? The Agenda of Varian Fry and the Emergency Rescue Committee. In Exiles+Emigres. The Flight of European Artist from Hitler. Edited by Stephanie Barron. Los Angeles: LA County Museum of Art, pp. 100-9.

Koldehoff, Stefan. 2011. Plötzlich dieser Überschuss. Die Welt. June 6. Available online: https://www.welt.de/ print/wams/kultur/article13425973/Ploetzlich-dieser-Ueberschuss.html (accessed on 17 August 2020).

Kuon, Peter. 2008. Les Images d'ailleurs dans les récits de déportation. In Exils, Migrations, Création. Exil Anti-Nazi, Témoignages Concentrationnaires. Edited by Jürgen Doll. Toronto: Indigo, Marne-la-Vallée: Université Marne-la-Vallée, pp. 171-79.

Leiris, Michel. 1929. Dictionnaire critique: Civilisation. Documents 4: 221-22.

Leiris, Michel. 1930. L'Cil de l'ethnographe (À propos de la Mission Dakar-Djibouti). Documents 7: 404-14.

Mahon, Peter. 2017. Posthumanism. A Guide for the Perplexed. London: Bloomsbury.

Mathieu, Georges. 1963. Au-delà du Tachisme. Paris: René Julliard.

Mehring, Christine. 1999. Wols Photographs. Cambridge: Busch-Reisinger Museum, Harvard University Art Museums.

Mémoire du camp des Milles. 2013. Mémoire du camp des Milles 1939-1942. Marseilles: Métamorphoses/Le Bec en L'air. Michaud, Éric. 1997. Fabriques de L'homme Nouveau: De Léger à Mondrian. Paris: Éditions Carré.

Paire, Alain. 2013. Hommes de brique. In Ernst, Springer, Wols au Camp des Milles. Edited by Béatrice Caille and Juliette Laffon. Aix-en-Provence: Fondation du Camp des Milles, Paris: Flammarion, pp. 63-70.

Petersen, Hans-Joachim. 2010. Wols. Les Aphorismes. Paris: Flammarion.

Rathke, Ewald. 2013. On the Biography of the Art of Wols. In Wols. Retrospective. Edited by Toby Kamps. Houston: The Menil Collection, Munich: Hirmer, Bremen: Kunsthalle Bremen, pp. 34-54.

Restany, Pierre. 1962. Une peinture existentielle: Wols. xx $x^{e}$ Siècle 24: 53-56.

Sartre, Jean-Paul. 1948a. Visages. Paris: Seghers.

Sartre, Jean-Paul. 1948b. Nourritures. Paris: Jean Damase.

Sartre, Jean-Paul. 1964. Doigts et non-doigts. Situations IV: 408-34.

Siegel, Katy. 2011. Since '45. America and the Making of Contemporary Art. London: Reaktion Books.

Siegel, Katy. 2013. Undoing Wols. In Wols. Retrospective. Edited by Toby Kamps. Houston: The Menil Collection, Munich: Hirmer, Bremen: Kunsthalle Bremen, pp. 78-85.

Slavkova, Iveta. 2004. Circus Wols: Le testament de Wols au camp des Milles. In Les Écrits D'artistes Depuis 1940. Edited by Françoise Levaillant. Caen: IMEC, pp. 145-57.

Slavkova, Iveta. 2011. La bouteille de Wols, la plume de Sartre et une histoire à réécrire. Food and History 9: 85-102. [CrossRef]

Slavkova, Iveta. 2018. Entre charme et effroi. Circus Wols, le récit de Wols des années terribles. In La France en guerre. Cinq «Années Terribles». Edited by Jean-Claude Caron and Nathalie Ponsard. Rennes: Presses Universitaires de Rennes, pp. 327-43.

Tapié, Michel. 1951. Véhémences Confrontées: Bryen, Capogrossi, De Kooning, Hartung, Mathieu, Pollock, Riopelle, Russell, Wols (March 8-31). Paris: Galerie Nina Dausset.

Taylor, Sue. 2000. Hans Bellmer: The Anatomy of Anxiety. Cambridge and London: MIT Press.

Toloudis, Constantin. 1980. Jacques Audiberti. Boston: Twayne Publishers.

Vallier, Dora. 1998. L'Art abstrait. Paris: Hachette. First published 1980.

Van Damme, Claire. 1985a. Wols. Aforismen en Kanttekenningen. Ghent: Drukkerij Goff.

Van Damme, Claire. 1985b. Wols. Biografische Documenten. Ghent: Drukkerij Goff. 
Van Damme, Claire. 1985c. Wols. Brieven van e aan Wols. Ghent: Drukkerij Goff.

Van Damme, Claire. 1986. Le bateau ivre. Biographie critique et documentée de l'artiste. Wols (1913-1951). In Wols sa vie ... . Edited by Gerhard Götze. Paris: Goethe Institute, n.p.

Verspohl, Franz-Joachim. 1991. Post-war Debates: Wols and the German reception of Sartre. In The Divided Heritage. Themes and Problems in German Modernism. Edited by Irit Rogoff. Cambridge: Cambridge University Press, pp. 50-74.

Wols. 1945. Wols. Paris: Jean Belmont/Galerie Drouin.

Wols. 1989. Wols. Bilder, Aquarelle, Zeichnungen, Photographien, Druckgraphic. Zürich: Kunsthaus.

Wols. 2013. Wols Retrospective. Edited by Toby Kamps. Houston: The Menil Collection, Munich: Hirmer, Bremen: Kunsthalle Bremen.

Wols, fund Iliazd. 1940-1944. Archives, Dieulefit, Fund Iliazd (Ili 37-39). Paris: Bibliothèque Kandinsky, Centre Pompidou.

(C) 2020 by the author. Licensee MDPI, Basel, Switzerland. This article is an open access article distributed under the terms and conditions of the Creative Commons Attribution (CC BY) license (http://creativecommons.org/licenses/by/4.0/). 